NBER WORKING PAPER SERIES

\title{
A TIME TO MAKE LAWS AND A TIME TO FUNDRAISE? ON THE RELATION BETWEEN SALARIES AND TIME USE FOR STATE POLITICIANS
}

\author{
Mitchell Hoffman \\ Elizabeth Lyons \\ Working Paper 22571 \\ http://www.nber.org/papers/w22571 \\ NATIONAL BUREAU OF ECONOMIC RESEARCH \\ 1050 Massachusetts Avenue \\ Cambridge, MA 02138 \\ August 2016
}

This paper represents a revision of an earlier working paper, "Do Higher Salaries Lead to Higher Performance? Evidence from State Politicians," to focus on time use. We thank Alan Auerbach, Kevin Bryan, Varanya Chaubey, Decio Coviello, Dan Elfenbein, John de Figueiredo, Rui de Figueiredo, Fred Finan, Yosh Halberstam, Nikolaj Harmon, Deepak Hegde, Gianmarco Leon, Dan Mitchell, Naci Mocan, John Morgan, Gerard Roland, Michel Serafinelli, Orie Shelef, Nathan Yang, and various seminar participants for helpful comments. We are grateful to Ernesto Dal Bo and Enrico Moretti for sharing data with us, as well as to Kathleen Bratton, Ray Fisman, and James Snyder for sharing data that were used in an earlier version of the paper. Kevin (Hongjia) Hu, Ania Jaroszewicz, Palermo Penano, Nicholas Roth, Kristjan Sigurdson, and Trent Turnbull provided outstanding research assistance. Financial support from the Kauffman Foundation, the National Science Foundation IGERT Fellowship, and the Social Science and Humanities Research Council of Canada is gratefully acknowledged. The views expressed herein are those of the authors and do not necessarily reflect the views of the National Bureau of Economic Research.

NBER working papers are circulated for discussion and comment purposes. They have not been peer-reviewed or been subject to the review by the NBER Board of Directors that accompanies official NBER publications.

(C) 2016 by Mitchell Hoffman and Elizabeth Lyons. All rights reserved. Short sections of text, not to exceed two paragraphs, may be quoted without explicit permission provided that full credit, including $\odot$ notice, is given to the source. 
A Time to Make Laws and a Time to Fundraise? On the Relation between Salaries and Time Use for State Politicians

Mitchell Hoffman and Elizabeth Lyons

NBER Working Paper No. 22571

August 2016

JEL No. D72,H70,M52

\begin{abstract}
$\underline{\text { ABSTRACT }}$
Paying higher salaries is often believed to enhance worker effort, leading workers to work harder to avoid getting fired. However, workers may also respond to higher salaries by focusing on tasks that most directly affect getting fired (as opposed to those that contribute most to productivity). We explore these issues by analyzing the relationship between the level of compensation and time use for US state legislators. Using data on time use and legislator salaries, we show that higher salary is associated with legislators spending more time on fundraising. In contrast, higher salary is also associated with less time spent on legislative activities and has no clear relation to time spent on constituent services. Subgroup analysis broadly supports our interpretation of the data.
\end{abstract}

Mitchell Hoffman

Rotman School of Management

University of Toronto

105 St. George Street

Toronto, ON M5S 3E6

CANADA

and NBER

mitchell.hoffman@rotman.utoronto.ca

Elizabeth Lyons

School of Global Policy and Strategy

University of California, San Diego

9500 Gilman Drive, MC 0519

La Jolla, CA 92093-0519

lizlyons@ucsd.edu 


\section{Introduction}

The relationship between voters and politicians is a classic example of the principal-agent problem (Barro, 1973). In this problem, like many others, it is difficult for the principal to accurately evaluate the performance of the agent due to a noisy relationship between the agent's inputs and outcomes. An alternative to measuring outcomes for evaluating an agent's performance is to examine how she uses her time. Politicians may spend their time enacting laws and serving constituents. Alternatively, they may spend their time on fundraising, outside work, or leisure, potentially leading to worse outcomes for voters. Unfortunately, it is difficult to measure how politicians use their time as they do not work under the close supervision of the principal (the general public). As a result, little is known about how politicians actually use their time, or about how incentives affect their time use.

Concerns about suboptimal politician productivity and time use emerge forcefully in the context of US state government. It is sometimes argued that state legislators spend excessive time on fundraising. ${ }^{1}$ As a consequence, they may have too little time to fulfill their other duties. While state legislatures differ in many features such as whether the legislator position is a full-time position or not, one particularly striking difference across legislatures is in the level of compensation. Some states like California pay legislatures a salary on the order of $\$ 100,000$. Other states like New Mexico and Texas pay much lower salaries around $\$ 5,000$ or less. $^{2}$

This paper studies the relationship between the level of salary for state politicians and how politicians spend their time. The level of compensation can have a variety of theoretical effects on a workforce, potentially selecting better workers (Weiss, 1980), as well as incentivizing them to work

\footnotetext{
${ }^{1}$ For example, in a survey of state legislative candidates, Francia and Herrnson $(2003)$ find that candidates spend roughly one quarter of their campaign time on fundraising. David Jolly, a congressman from Florida, proposed the "Stop Act" in 2016 to prohibit federal officeholders from directly soliciting contributions; Jolly has declared that "Members of Congress spend too much time raising money and not enough time doing their job" (see the 60 Minutes piece on "Are Members of Congress Becoming Telemarketers?" on April 24, 2016). For a popular discussion of excessive time on fundraising for US politics, see Last Week Tonight with John Oliver on 4/3/2016. For state legislative races, in particular, there is growing concern about the need to raise large sums of campaign money; see, e.g., "Money pours into Minn. legislative campaigns" by Catherine Richert, http://www.mprnews.org/story/2012/11/05/ politics/legislative-races-money.

${ }^{2}$ It is argued that lower salaries may contribute to low performance. For example, the Council of State Governments, a national organization representing state governments, often argues that low legislative compensation has deleterious consequences, stating "If legislators are not paid adequately, then candidates are drawn from a smaller pool. ... You can't expect to attract good candidates with pay that is lower when compared to other jobs and professions (quotation from Keon Chi, editor-in-chief of the Council of State Government's Book of the States). Quoted in "Legislators' pay falling behind" by Eric Kelderman, a February 13, 2007, article on Stateline.org. General popular discussion on whether politicians should be paid more is also very common. For example, business magnate Richard Branson in a July 13, 2013 blog post entitled, "Should politicians be paid more?" argues that increasing pay is critical for attracting high-quality politicians in the context of discussion on whether to raise pay for members of British Parliament.
} 
harder so as to avoid getting fired (Becker and Stigler, 1974; Shapiro and Stiglitz, 1984). However, compared to work on incentive pay, there is more limited empirical research on the level of pay. As recognized in the work on incentive pay, increases in compensation may not necessarily lead to improvements in the overall quality of the work performed, particularly for multitask jobs (Holmstrom and Milgrom, 1991). It is well recognized, for example, that giving teachers bonuses based on student test scores might lead teachers to strongly emphasize teaching activities that improve test scores and to de-emphasize other learning activities that may be beneficial to students, but do not improve test scores. Likewise, if the level of teacher pay is significantly increased, thereby significantly increasing the cost of getting fired, teachers may focus on activities that most decrease the chance of getting fired (as opposed to those that give the highest, long-run benefits to students). Turning back to politicians, if politician salary is higher, politicians may devote more effort to activities that increase their likelihood of being elected, but, that given the problems associated with monitoring their inputs, may not lead to better outcomes for voters. By studying time use empirically, we can examine whether such behavior may occur.

Beyond this, there are multiple other reasons to study politician time use. First, what politicians do on a day-to-day basis has often been a "black box" for researchers. Second, there are challenges in measuring politician productivity. For example, it is hard to say whether a legislature should be deemed more productive when it has higher or lower expenditures. Measures like the number of bills passed or proposed are also controversial because bills differ widely in their importance. ${ }^{3}$ Third, there has been little work on politician time use, despite the potential for time use data to overcome some of the difficulties associated with measuring politician effort. To our knowledge, our paper represents the first study in economics on politician time use.

To measure how politicians spend their time, we take advantage of rich, confidential surveys conducted by political scientists (Carey et al. 1995, 2002). In 1995 and 2002, state legislators were asked how much time they spent on various activities on a 1-5 scale. A central concern for any study of politician time use is whether we can trust the time use data. Two key features of our data address this concern. First, the politicians were informed truthfully that their confidentiality would

\footnotetext{
${ }^{3}$ In addition, the number of bills passed may be strongly affected by the structure of the legislature and the party in power, as well as the identity of the governor (e.g., a Republican governor may veto bills by Democratic legislators). Moreover, anticipating a possible veto, some bills may not be proposed in the first place. Finally, if a legislature is functioning well and addressing a state's more important issues, there may be much less need of passing new bills in a particular year.
} 
be protected. As such, outside researchers can only match politicians by state (and cannot do so by person). Second, the surveys covered many different topics, with only a small section on time use. As such, we are much less concerned that politicians might be selecting into the survey based on how they use their time.

We find a significant positive association between the level of pay and time spent fundraising. All else equal, when politicians are paid higher salaries, they spend significantly more time on fundraising, particularly on fundraising for themselves (as opposed to for their party). In contrast, higher salary also is associated with politicians spending less time on legislative activities and has no relation to time spent on constituent services. These relationships are robust to the gradual inclusion of more and more controls, including those for legislature characteristics (including professionalism controls), state characteristics, region controls, and legislator characteristics. To probe our fundraising results further, we analyze how the relation between salary and fundraising varies across different subgroups.

Our study contributes to a growing economics literature on the impact of politician salary. In economic theory, there is substantial work analyzing the impact of politician salary (e.g., Besley, 2004; Caselli and Morelli, 2004; Mattozzi and Merlo, 2008; Messner and Polborn, 2004; Poutvaara and Takalo, 2007). This work points out that the impact of increasing salary is not always straightforward, often because of various selection effects. Our paper takes a different approach, focusing on how salary affects politicians' choices among different time "inputs" as opposed to how it affects selection. In empirical work, Ferraz and Finan (2010) and Gagliarducci and Nannicini (2013) study the impact of politician salary for Brazilian municipal legislators and Italian mayors, respectively. For these politicians, salaries change discontinuously with city population, allowing for regression discontinuity estimates of the impact of salary. Fisman et al. (2015) and Mocan and Altindag (2013) study the impact of salaries for Members of the European Parliament (MEPs), exploiting a recent pay equalization policy that significantly increased salaries for MEPs from certain countries. Kotakorpi and Poutvaara (2011) analyze a recent pay increase for Finnish parliamentarians. These papers mostly tend to find often substantial positive impacts of salary on competitiveness, selection, and performance. ${ }^{4}$ Though we lack a clean regression discontinuity strategy or natural experiment as in

\footnotetext{
${ }^{4}$ For electoral competitiveness, Ferraz and Finan $(2010)$ and Fisman et al. $(2015)$ find large positive impacts on whether politicians seek re-election. For selection, Ferraz and Finan (2010), Gagliarducci and Nannicini (2013), and Kotakorpi and Poutvaara (2011) find large positive impacts on politician quality, whereas Fisman et al. (2015) find
} 
several of the above papers, our paper suggests a potential drawback from higher salaries, namely, that they could drive politician time use toward fundraising.

While other empirical work studies the impact of politician salary outside the US, we know of very little prior empirical work on the impact of politician salary in the US. ${ }^{5}$ In economics, the only work on US politician salary we are aware of is by Diermeier et al. (2005) and Keane and Merlo (2010). These two papers estimate structural models of career decisions for US congressmen. Their counterfactual simulations include an investigation of how changes in congressional wages affect congressional career decision-making. Our reduced form approach complements their structural approach. Given that there is very little work on US politician salary, some of the most related work to our paper is arguably that on other institutions for US politicians, such as term limits (Besley and Case, 1995; List and Sturm, 2006), term length (e.g., Kalt and Zupan, 1990, Titiunik, 2014), and district size (e.g., Baqir, 2002, Gilligan and Matsusaka, 1995).

Within political science, there is a small literature on time use by candidates or politicians. On candidates, for example, Francia and Herrnson (2003) and Miller (2016) examine aspects of time use in state legislative candidates as opposed to elected legislators. ${ }^{6}$ On politicians, we are also aware of a few papers that use some of the time use data we study, though for different purposes. Using the 2002 survey, Kurtz et al. (2006) study legislators' perceptions about how "full-time" their job is. ${ }^{7}$ Also using the 2002 survey, VanDusky-Allen (2014) examines the relation between term limits and time spent on constituent services and fundraising. ${ }^{8}$ Probably most related to our paper is a book by Powell (2012). The book is primarily focused on understanding the extent to which campaign contributions influence or corrupt public policy in state legislatures. As part of this exercise, one of the book's chapters (Chapter 4) looks at how different factors relate to time spent on fundraising and negative impacts on politician quality. (For Kotakorpi and Poutvaara (2011), positive impacts are only observed for female candidates.) For political performance, Ferraz and Finan (2010) and Gagliarducci and Nannicini (2013) find large positive impacts on legislative productivity, whereas Fisman et al. (2015) find zero effect.

${ }^{5}$ In political science, we have found some papers that have included salary in some analyses related to state legislatures (Berkman, 1994, Fiorina, 1994, Squire, 1997), but the focus of these papers is not on the impact of politician salary. In economics, Besley (2004) shows that higher salary for governors is associated with greater ideological congruence between governors and their electorate. Although not directly related to our paper, two papers in political science, Groseclose and Krehbiel (1994) and Hall and Van Houweling (1995), show that US congressmen respond to financial incentives to retire.

6 Francia and Herrnson (2003) examine how public finance laws affect the time that state legislative candidates spend on fundraising. Miller (2016) examines the relationship between time spent on fundraising and vote share. However, we are not aware of work with candidates analyzing how salary relates to time use.

${ }^{7}$ The authors include legislator compensation as a control in one regression. There is a positive relation between salary and a legislator's perception of what percentage of a full-time job is the job as legislator.

${ }^{8}$ To address this, we control for whether there are term limits in our baseline controls. VanDusky-Allen (2014) does not control for salary, but does control for a general measure of legislature professionalism. 
campaigning using the 2002 wave of the survey we use in our analysis. Like us, she finds a positive relationship between legislator compensation and time spent on fundraising.

Besides the difference in focus, our study differs from the analysis in Chapter 4 of Powell (2012) in many ways. First, Powell (2012) focuses exclusively on time on fundraising, whereas we also study time spent on legislative activities, constituent services, and work outside of politics. We believe this is important from both a conceptual and empirical standpoint. Specifically, it is important to understand whether higher salaries entail a potential trade-off or whether they simply increase time spent on all political activities. Second, we perform theoretically grounded analyses of how estimates vary across subgroups, whereas Powell (2012) does not perform subgroup analyses. Third, we use different empirical specifications. Our analysis is based on regression models, including those in the tradition of Altonji et al. (2005) where additional controls are gradually added. ${ }^{9}$ Fourth, our sample size is significantly larger, as we study both the 1995 and 2002 survey waves (instead of simply the 2002 survey wave). ${ }^{10}$

Our work also relates to research on the time use of other prominent individuals such as CEOs (Bandiera et al. 2013), as well as to general analyses of time use (Becker, 1965; Hamermesh and Pfann, 2005).

Our paper proceeds as follows. Section 2 provides further relevant institutional context on state legislatures. Section 3 describes the data sources. Section 4 shows results. Section 5 concludes.

\section{Institutional Context}

We first provide a brief overview of responsibilities and compensation for state legislators in order to give context to our analysis. Then, in Section 2.3. we provide theoretical discussion on how salaries may affect politician time use.

\subsection{Being a State Legislator}

State legislators in the US are responsible for many aspects of government. States provide a variety of services including those related to education, healthcare, and prisons (e.g., Rehavi, 2007). Each

\footnotetext{
${ }^{9}$ Powell (2012) uses a multi-level hierarchical model.

${ }^{10}$ Our main results have about 6,300 observations. In contrast, the results in Chapter 4 of Powell (2012) have about 2,000 observations for the individual-level analysis. Further, in Chap. 4 of Powell (2012), legislator pay is only analyzed as part of analysis at the state-chamber level, where there are 88 observations (and only 6 independent variables).
} 
state has approximately 50 to 400 legislators.

Legislators vary substantially across states in the time commitment involved. Many legislatures meet every year, whereas others meet every other year (though this has become less prevalent over time, and currently only six legislatures are biennial). Some legislatures are in session for most of the year, whereas other legislatures meet for a few months. In our empirical analysis, we will control for frequency of meeting, as well as session length.

Legislator serve terms of four years or of two years. In order to get re-elected, legislators devote substantial time to fundraising. The demands of fundraising for federal congresspeople are well understood, even in the popular press. However, state legislators also raise sizable sums of money for their election campaigns (Gierzynski and Breaux, 1996). In some states, there are term limits, which limit the number of terms a legislator can serve.

Of course, legislators are also involved in developing and learning about new legislation. Legislators come from many backgrounds and often serve constituents with widely varying interests. Thus, theoretical work has emphasized the importance of building coalitions in order for legislation to pass (e.g., Groseclose and Snyder, 1996).

In addition, legislators report spending significant time on serving constituents (Freeman and Richardson Jr, 1996). Casework can take many forms, e.g., helping a constituent learn about or receive a benefit that the constituent is eligible for. National Conference of State Legislatures (2000) and Kurtz et al. (2006) note that legislators can even personally become physically involved in casework, such as personally cutting down weeds blocking a highway.

\subsection{Legislator Salaries}

While nominal salaries for legislators averaged across all states have been increasing at a steady clip, there is substantial variation both within and across states. Our analysis relies heavily upon crossstate salary variation, so it is key to understand its drivers. In addition, it is also useful to briefly explain how salaries have changed over time in order to provide context on why different states had different salaries in the survey years (1995 and 2002).

How pay is determined varies across states. In $16 \%$ of the contiguous 48 states, pay for legislatures was determined exclusively by a state compensation commission in 2001. Commissions set salaries based on a number of criteria, including the pay of other government officials and bureaucrats. 
In a relatively small number of the contiguous states, $8.3 \%$ in 2001 , pay was set exclusively by the constitution. In states where pay is constitutionally determined, it is changed only if the constitution is amended. In $35 \%$ of states in 2001 legislator pay was exclusively set by statute, either a law outside the constitution, or the legislators essentially set their own pay by passing compensation bills. In many cases, legislators vote on their own pay, but the increases only take effect for the next term. ${ }^{11}$ Many states use more than one method to set legislator pay with 3 states in 2001 using all three pay setting methods. ${ }^{12}$

Several factors affect the level of pay. First, salaries have increased as legislatures have become more "professionalized." In the past, many legislatures would meet every other year or be in session for only several months. In the mid 20th century, however, legislatures began a shift toward increased responsibilities. As of 2010, only five legislatures meet bienially: Montana, Nevada, North Dakota, Oregon, and Texas. The National Conference of State Legislatures classifies states into categories based on whether their legislatures are full-time or part-time. Ten states are categorized as full-time or almost full-time, and the rest are considered as part-time or almost part-time (National Conference of State Legislatures, 2009). In general, full-time legislators tend to receive higher pay. In all our analyses, we control for length of legislative sessions in days, probably the most important measure of session length, and we also explore other measures of professionalization such as a legislator's number of staff. ${ }^{13}$

Second, as documented by Di Tella and Fisman (2004), US governor salaries have often been increased in response to economic growth. As the economy improves and there are greater tax revenues at both the national and state level, salaries for politicians tend to increase. To account for this possibility in our regressions, we control for state GDP (though the reader should bear in mind that we study legislators, while Di Tella and Fisman (2004) study governors).

Third, even conditional on professionalization and economic growth, as well as other differences across states, there are a substantial number of large, and seemingly irregular salary changes in the historical record. As an example, consider the nearby states of Michigan and Minnesota. In the 1980s

\footnotetext{
${ }^{11}$ Per the 27 th amendment to the US constitution passed in 1992, this is the method use by the US congress in setting its compensation.

${ }^{12}$ In 2001, 1 state used both a compensation commission and the constitution to set pay, about $19 \%$ of states determined pay both by statute and the constitution, and $12.5 \%$ of states set pay by both statute and compensation commission.

${ }^{13}$ Although many legislatures have historically been part-time, many legislators perceive the job as being full-time or close to it (Kurtz et al. 2006).
} 
and 1990s, legislator salaries were higher in Michigan than in Minnesota, but both were growing at a slow, steady rate. In 2000, Michigan legislators made $\$ 55,054$ per year and Minnesota legislators made $\$ 31,440$. However, due to a vote of the Michigan Compensation Commission, salaries were increased roughly $40 \%$ from $\$ 55,054$ to $\$ 77,400$, where it remained at a roughly similar level throughout the 2000s. In contrast, the Minnesota salary stayed flat during this time period. Or in another example, legislator salary in Oklahoma increased by $60 \%$ in 1990 , from $\$ 20,000$ to $\$ 32,000$, a change which were not observed in nearby states.

The form of legislative compensation differs across states. In some states, legislators are paid a yearly annual salary. For example, in California, legislator pay was $\$ 99,000$ per year in the 2002 Book of the States ( $\$ 118,074$ in 2009 dollars). This amount is paid irrespective of the number of days the legislature meets. In other states, legislators are paid a daily wage. ${ }^{14}$

\subsection{Theoretical Framework: How Might Salaries affect Legislator Time Use?}

Having discussed what legislators do and how they are paid, how do these factors relate? We provide qualitative discussion on this question (in keeping with the empirical focus of our paper), but provide formal arguments in Appendix C.

For simplicity, suppose that politicians can spend their time on two activities: legislative activities and fundraising. All else equal, politicians prefer to engage in legislative activities relative to fundraising, either because politicians view legislative activity as socially desirable or because fundraising is very unpleasant. Both legislative activities and fundraising affect the probability of getting re-elected, but we assume there is a greater return from fundraising. ${ }^{15}$

When salaries are higher, politicians face a greater incentive to get re-elected (as the value of serving in office is greater). Thus, they will optimally respond by increasing the time spent on fundraising. They do this even though voters care about the time they spend on legislative activities.

This argument does not require that salaries are the only "compensation" that politicians receive from their office. In reality, there are many other potential benefits to serving in office,

\footnotetext{
${ }^{14}$ In Vermont, legislators receive a weekly wage.

${ }^{15} \mathrm{We}$ are not aware of empirical evidence supporting that fundraising matters more than legislative activities for getting re-elected. However, as discussed further in Appendix C there is evidence that fundraising and political advertising matter for elections (see, e.g., Spenkuch and Toniatti (2016) for recent, careful evidence of sizable effects; we caveat, though, that not all the literature finds positive effects (e.g., Levitt, 1994)). Given politicians' often expressed dislike for fundraising (discussed further in Appendix C), it seems unlikely that politicians would spend time fundraising if it didn't yield electoral benefits relative to spending the time on legislating. It is likely easier for most voters to see a campaign ad on TV than to accurately observe whether politicians are spending time on legislative activities.
} 
including perks from being in office and post-office career rewards (e.g., getting to serve as a lobbyist or getting to run for a higher office in the future). However, individuals who receive a lot of "nonpecuniary value" from serving in office seem likely to have time use patterns that are less shaped by salary. ${ }^{16}$ Legislators having a high outside option outside of politics should work in the opposite direction of legislators having non-pecuniary value from the office. ${ }^{17}$

One interesting feature of US state legislature elections is that many elections are non-competitive, with only one candidate running or with one candidate obtaining a very large share of the vote. However, it is not immediately clear how electoral competitiveness will affect the relation of salary and time spent on fundraising.

\section{Data}

We describe the main features of our data here. Further details are given in Appendix A.

\subsection{Time Use Data}

Information on politician time use was collected from the survey of legislators done by Carey et al. (1995) and Carey et al. (2002). Surveys were conducted through the mail and respondents were promised confidentiality. The 1995 survey was mailed to every upper house legislator and $77 \%$ of lower house legislators. In addition, it was mailed to all former legislators who last served in 1993 or $1994 .{ }^{18}$ For the 1995 survey, there were 3,542 legislators who responded and the response rate was $47 \%$. The 2002 survey was mailed to all state legislators. There were 2,982 state legislators who responded and the response rate was $40.1 \%$. Questions asked on time use differ across the two years. These differences are specified in Appendix A. State legislators were asked to report how much time they actually spent on one of several activities going from $1=$ "Hardly Any" to $5=$ "A Great Deal." 19

\footnotetext{
${ }^{16}$ In the paper, we use the term "non-salary benefits" to refer to other money paid by the state to the legislator during the year as part of his or her compensation (such as per diem pay or miles reimbursement). We use the term "non-pecuniary benefits" or "non-pecuniary value" to refer to other benefits of serving or having served in office; this includes non-monetary benefits (such as enjoyment from being in power), as well as monetary benefits, such as the money one can get from being a lobbyist in the future.

${ }^{17}$ Specifically, legislators who have a high outside option should have their time on fundraising more responsive with respect to salary than legislators with lower outside options.

${ }^{18}$ In the 1995 survey, $21 \%$ of respondents were former legislators. We believe these data are still informative because the legislators served quite recently. However, our results are robust to dropping these prior office holders from our sample.

${ }^{19}$ In the wording of the question, only the end points of the scale are defined (i.e., there's no definition for a response of 2,3 , or 4 ). The 1995 survey has these end-points in reverse such that $5=$ "Hardly Any" and $1=$ "A Great Deal". We
} 
We normalize these variables to use as outcomes in our analysis (normalized by year).

For most of the analysis, we group time use questions into three categories: legislative activities, constituent services, and fundraising/campaigning. When there are multiple questions per category, the category is defined as the average of the normalized values. (This approach of taking the average of z-scores is shared with other papers such as Bloom et al. (2015).) We define the legislative activity category using time spent on studying proposed legislation, developing new legislation, building coalitions within the party, and building coalitions across paries. We define the constituent services category using time spent on helping constituents and on staying in touch with constituents. The fundraising/campaigning category is given by one question on fundraising/campaigning. We focus on questions that are asked across both years of the survey. ${ }^{20}$

Data Reliability. As with most survey data, a basic concern is whether the data are reliable, i.e., do they reflect true information on politician time use? For example, politicians may be loathe to report that they spend little time actually attending to legislation and serving the public. One key defense against such social desirability bias is that the data were collected through confidential mail surveys (as opposed to interviews). Thus, provided legislators trusted that the survey was confidential, there would be little benefit from lying. Separate from social desirability pressure, another question is whether the politicians provided serious and attentive answers to the time use questions. While it is difficult to address this issue directly, we note to the reader that the time use questions appeared in the middle of the survey form. ${ }^{21}$

It is quite possible, however, that there is noise in how politicians responded to the time use questions. Given our focus on time-use as a dependent variable, this will not bias our results if the noise in survey response is classical measurement error. One possible version of non-classical measurement error that relates to salary is that politicians in states with higher salary may feel that they ought to report spending more time "serving the public." That is, individuals who are better re-code the scale to match that of 2002 in the data.

${ }^{20}$ In each survey, there was also a question about time spent on making sure one's district receives "a fair share of government money and projects." Ensuring one's district receives a fair share of government money seems a bit different to us than communicating with or helping one's constituents (as legislation may also be involved), so we have not included it as part of constituent services. However, if we include time spent on ensuring a fair share for one's district as part of the definition of time spent on constituent services, our main results in Table 2 are substantively unchanged. The ensuring a fair share for one's district question is analyzed separately in Table 4

${ }^{21}$ One possible downside to long surveys is that respondents become bored or fed up and begin giving the easiest responses rather than the honest ones. However, this shows up near the end of the surveys, rather than in the middle where the time use questions are placed (Herzog and Bachman, 1981). 
compensated might feel more social pressure to exaggerate what they have done for their state or constituents, and to understate time spent fundraising. While we cannot rule this out, we point out that such responses would go in the opposite direction of our findings. Correcting for such bias would seem likely to make our findings stronger. ${ }^{22}$

Non-response Bias. Even if politicians respond truthfully to the survey, bias could also emerge due to differential non-response. We consider two main possibilities. First, legislators who are more altruistic may be more likely to respond to the survey (Jones and Linda, 1978). This is similar to a social desirability bias in that we would have the sample of legislators who are "better behaving" and our data would be biased towards time use that is more consistent with what legislators are supposed to do rather than what they are doing. If this is true, then our estimates are a lower bound on how much time legislators devote to fundraising and campaigning as opposed to legislative activities. In addition, the survey was not framed as a study of time use, and time use was a small part of the total survey. As a result, we believe that it is unlikely that legislators selected out of the survey based on their time use (Levitt and List, 2011$)$.

Second, legislators who have more free time on their hands may be more likely to respond (e.g., Tomaskovic-Devey et al., 1994). Although we try to control for how much responsibility legislators have through our measures of legislature professionalization (described below), there may be unobservable reasons why some legislators have more time on their hands than others and these unobservables may also correlate with legislator salary. If we have the sample of legislators with the most spare time, then we may have lower bounds on all measures of time use. As a result, it could be that we are underestimating the effects of salary on legislative activities, constituent services, and fundraising and campaigning. We test whether response rates differ depending on legislator salary, and find that, conditional on our controls for legislature and state characteristics, there is no relationship between salary and response rates (see Appendix Table B2). This finding reduces our concerns that response bias is confounding our findings.

Descriptives. Figure 1 presents histograms of time use across the three main categories: legislative activities, constituent services, and fundraising/campainging. (Appendix Figure B1 presents histograms for individual time use questions (also referred to as "narrow categories") as opposed to

\footnotetext{
${ }^{22}$ It is also possible to conceive of bias that would go in the same direction of our results, e.g., higher salaries might conceivably introduce a stronger sense of "entitlement" to the job, and this could make someone more likely to lie about spending time serving the public. Such a bias seems less plausible to us than the bias in the opposite direction.
} 
the three main categories.) In Figure 1, note that panel (a) is based on four questions, panel (b) is based on two questions, and panel (c) is based one question, reflecting what data are available on the different categories.

As seen in Figure 1, and as detailed further in Table 1, legislators' average time use is highest on constituent services, where the average response is 4.1 of 5 . For legislative activities, the average answer is a bit lower at 3.4, and it is lowest for fundraising/campainging at 2.4 of 5 . However, there is considerable variation across legislators on all the categories. Still, there are fewer instances of legislators reporting spending more time on fundraising/campaigning than on legislative activity or on constituent services. Only $19 \%$ of respondents have a lower number for the legislative activity category than for fundraising/campaigning, and only $6 \%$ have a lower number for the constituent services category than for fundraising/campaigning. Also, $6 \%$ have the same number for the fundraising and legislative activity categories, and $9 \%$ have the same for fundraising and constituent services.

Panel B of Table 1 demonstrates how our main time use categories (i.e., legislative activities, constituent services, and fundraising and campaigning) correlate with one another. The correlation between time use categories is positive, though not particularly large. ${ }^{23}$

In the surveys, politicians are also asked whether they were the primary author of a bill that passed. This question enables us to see whether there is a relation between time use on various categories and an actual legislative outcome, namely, whether one authored a bill that passed. Consistent with time spent on legislative activities being important for legislative outcomes, Appendix Table B3 shows that time on legislative activities is significantly correlated with the number of passed bills a legislator was a primary author on. A standard deviation increase in time on legislative activities is associated with being the primary author on 0.3 more bills that passed. In contrast, the association is much smaller between our other time use measures and this bill-passing outcome.

\subsection{Salaries}

We hand-collected politician salary data from the Book of the States, a periodical providing extensive information about policies and programs in different states. We create a single annual salary figure for each state by annualizing the relevant time frame. Salaries that are given for biennial legislative sessions are divided by two to obtain an annual salary figure. Daily salaries are multiplied by the

\footnotetext{
${ }^{23}$ This also seems to suggest that legislators who spend more time on a given category spend more time on the job overall.
} 
average number of days a legislature is in session over time.

We use real salaries deflating with the national CPI (2009 level). As in Di Tella and Fisman (2004), we ignore non-salary benefits that politicians receive (e.g., transportation expenses, living per diems, etc.) for our main results. States compensate non-salary expenses in different ways

(e.g., some provide reimbursement on actual expenses, which are unobserved to the econometrician, whereas other states give fixed amounts), thereby making it quite challenging to create a consistent measure of non-salary benefits across all states. We return to non-salary benefits again in Section 4.2.2, where we do a robustness check using some data on non-salary benefits.

For our main analysis, we use salary given in terms of tens of thousands of dollars (not in logged form). By using non-logged form, we capture the idea that increasing salary from $\$ 20,000$ to $\$ 80,000$ seems more consequential to a legislator than increasing salary from $\$ 2,000$ to $\$ 8,000$ even though both are the same in percentage terms.

\subsection{Other Characteristics of Legislatures and Summary Statistics}

From the Book of the States, we also hand-collected data on methods used to set salaries, session length over time, bill-passing over time, and on legislative support staff over time. We use the data on methods of compensation to help assuage concerns about endogenous wage-setting, examining how the impact of politician salary varies by method of compensation. Session length is an important control variable. Bill-passing is a standard measure of legislative productivity. We use data on legislative support staff as a control, one that is particularly useful in proxying a legislature's degree of professionalization over time.

Throughout the paper, we restrict attention to the 48 contiguous states (Hawaii and Alaska are excluded). Table 1 reports summary statistics on our outcome variables, salary, and primary controls.

\section{Results}

\subsection{Baseline Results on Salaries and Time Use}

Baseline Results. Table 2 reports our baseline estimates of the relationship between salary and legislator time use. At the legislator level, we regress normalized self-reported time use on legislator 
salary and controls. Standard errors are clustered at the state level (Bertrand et al., 2004).

Column 1 presents results with baseline controls (session length, upper house dummy, log state population, log state GDP, and a year dummy). The base controls help address some of the basic potential confounds, such as the possibility that economic conditions could influence both salary and politician time use. In column 2, we add "professionalization controls" (such as whether legislators have staff) to account for legislatures having different levels of professionalization, as we would like to isolate the role of salary compared to that of other aspects of professionalization.

In column 3, we would like to add geographic controls to account for states having persistent differences in politician behavior that could be correlated with salary (e.g., a culture of corruption that affects both the level of salary, as well as how politicians use their time). We lack sufficient variation between 1995 and 2002 in salaries to add state effects. So, instead, in column 3, we use census region fixed effects, as well as controls for state characteristics. The state characteristics are time-varying, so they also help address the possibility of a time-varying shock that affected both salaries and time use behavior. Column 4 additionally adds controls for legislator characteristics to achieve our full specification. This controls for differences across states in the characteristics of individuals who become state legislators. ${ }^{24}$

Panel A shows a negative and statistically significant relationship between salary and time spent on legislative activities. Because the dependent variable (time use) is normalized, the regression coefficients can be interpreted in terms of standard deviations.

Panel B examines the relationship of salary to time spent on constituent services. Unlike time spent on legislative activities, the coefficient here is positive. However, it is insignificant.

Panel C shows a significant positive relationship between salary and time spent on fundraising and campaigning. The relation remains strongly statistically significant even as more and more controls are added.

Magnitudes. How should we think about the magnitudes of the coefficients estimated? We start with the fundraising results where the estimated coefficients are largest in magnitude. The coefficients in Panel C range from 0.041 - 0.053. This implies that a $\$ 30,000$ increase in legislative salary, which would be a sizable increase, is associated with roughly a $0.12 \sigma-0.16 \sigma$ increase in time

\footnotetext{
${ }^{24}$ Salary may also have a direct effect on the characteristics of politicians. Thus, it is not clear we should be controlling for legislator characteristics if they are a possible mechanism by which salary affects time use. Thus, column 4 is the fullest specification, but for some readers, it may not necessarily be the most preferred specification.
} 
spent fundraising (where $\sigma$ stands for standard deviations). A $\$ 30,000$ increase in salary represents an increase in salary by about $1.25 \sigma$ (as Table 1 indicates the standard deviation of real salary is about $\$ 24,000$ ). Thus, our estimated coefficients seem moderate in size, though we admit that this is somewhat subjective.

In Panel A, the coefficient estimates are roughly around -0.03 . This implies that a $\$ 30,000$ increase in legislative salary is associated with roughly a $0.09 \sigma$ decrease in time spent on legislative activities. This is slightly smaller in magnitude than the coefficients in Panel C, but still seems non-trivial in magnitude.

Outside job. A limitation of the time use data is that we do not observe total time spent on politician activities vs. total time spent on non-politician activities. We do observe a proxy though in the form of whether a politician reports having a job outside of politics. ${ }^{25}$ Table 3 shows that paying a higher salary is associated with politicians being less likely to hold an outside job. This relation is significant even controlling for measures of legislature professionalization. A $\$ 30,000$ increase in salary is associated with roughly a $10 \%$ lower chance of having an outside job (as roughly implied by column 4$)$.

Narrower Time Use Categories. Table 2 focused on the three combined categories of time use. In Table 4, to delve further into how salary relates to time use, we narrow our definitions of the time use categories to particular questions. Column 1 indicates a significant negative relation between salary and time spent studying proposed legislation, whereas there is no significant relation between salary and time spent on developing legislation in column 2. Column 3 analyzes time spent on building coalitions within one's party, whereas column 4 analyzes building coalitions across parties. Salary has a negative association with both of them, though the coefficient for coalition building across parties is more negative. In columns 5 and 6 , we analyze time spent staying in touch with constituents and on helping constituents, respectively. Consistent with the combined measure of constituent services presented in Panel B of Table 2, there does not appear to be a relation between legislator salary and these sub-categories of constituent services. There is also no relation between salary and time spent on ensuring one's district receives a fair share of government money and projects in column 7 .

\footnotetext{
${ }^{25}$ For analysis of outside work done by Italian politicians, see Gagliarducci et al. (2010).
} 
In columns 8 and 9 , we break down time spent on fundraising by whether legislators were fundraising for themselves or fundraising for their caucuses. ${ }^{26}$ Again, consistent with our findings in Table 2, we find that a higher legislator salary does positively relate to time spent on fundraising. Interestingly, however, we only find a significant relationship between salary and fundraising for oneself and not for one's caucus. Column 8 implies that an increase in salary of $\$ 30,000$ is associated with legislators spending $0.15 \sigma$ more time on fundraising for themselves. ${ }^{27}$

\subsection{Robustness of Findings}

\subsubsection{Endogeneity Concerns}

A central concern for our analysis is that there is an unobserved factor that is correlated with both salary level and how politicians spend their time. We lack a quasi-experimental research design and cannot rule out all possibilities of endogeneity. However, we provide evidence and discussion regarding what we believe to be the most important potential sources of endogeneity. We do not believe that any of these are primarily driving our main result.

Endogenous Salary Setting. As described in Section 2.2, in some states, legislators often vote on their own salaries. One may be concerned that there could be an unrelated factor that affects the willingness of a state legislature to give itself a larger salary, as well as how legislators use their time. For example, if a legislature is more corrupt, the legislature may choose to pay its members high salaries, as well as spend more time on fundraising. A bias could also go in the opposite direction. For example, if legislators in one state are of unobservedly higher quality, they may be more able to command a higher salary from the public, as well as be more willing to spend more time on legislating.

To try to address this concern, we repeat our main, full-control time use analyses while restricting attention to states where legislators do not set their own salaries (i.e., we drop states where salary is only governed by statute). As seen in Appendix Table B4 the results are qualitatively similar to those in column 4 of Table 2 .

Professionalization and Unobserved State or Legislature Characteristics. Another

\footnotetext{
${ }^{26}$ The 1995 time use survey does not break down fundraising/campaigning time use into narrower categories, so these sub-categories are only available for 2002. Appendix Table A1 lists time use questions by year.

${ }^{27}$ This last finding, that salary is significant associated with fundraising for oneself, but not for fundraising for the caucus, is also found in Chapter 4 of Powell (2012).
} 
concern is that politician salary may related to unobserved legislature characteristics or state characteristics that also affect performance. Given the paper's focus on salary, a particular one to be mindful of is the degree of "professionalization" of state legislatures.

Historically, legislatures have differed significantly in the extent to which being a legislator was a "professional" position. The late 1960s and 1970s saw a large increase in the "professionalization" of state legislatures, where wages were increased, along with other changes such as lengthening legislative sessions and providing increased legislative staff (Fiorina, 1994). These changes differ by state, and have continued to the present, with gradually longer sessions and annual instead of bi-annual meetings.

Our main approach toward addressing the issue that professionalization could bias the results is to incorporate control variables for different aspects of professionalization. In Table 5 , our baseline controls include session length, which is an important measure of how much time being a legislator entails. With the professionalization controls in column 2 , we incorporate data on the frequency of meetings and on different dimensions of legislative staff. We think that controls for legislative staff might be particularly important with regard to time use because having more staff could be relevant for how legislators use their time.

Despite these controls, it is possible that salary may be correlated with unobserved legislature characteristics, e.g., the capital buildings or facilities. Alternatively, while we have controls for regions and some state characteristics, there may be important aspects of states that are difficult to measure. For example, in states where there are large differences across districts, legislators may face a harder time agreeing on which bills to pass (e.g., Dearden and Husted, 1993). We cannot eliminate these concerns entirely. We take comfort, however, in the fact that the coefficient on salary remains sizable even as increasingly more and more control variables are added (Altonji et al., 2005).

\subsubsection{Measurement}

Time. Different politicians could interpret the time use answers ( $1=$ "Hardly any" to $5=$ "A great deal") in different ways. "A great deal" of time for one person may only be a moderate amount of time for another. While our main approach has been to treat a politician's responses separately, an alternative is to look at the time use questions relative to one another. Specifically, we can define the "share of time" on an activity category as the amount of time on that category divided by the 
sum of the time on the three activity categories. Appendix Table B6 shows that the results from Table 2 are qualitatively robust to looking at share of time as the left-hand side variable instead of an absolute time measure.

As mentioned above, we do not measure a politician's total number of hours spent on political activities. However, there is a question in the 2002 survey that asks about what percentage of the individual's time is occupied with state legislator activities. Table B5 shows a positive relation between salary and share of time occupied with state legislator activities even while controlling for our full set of controls (including region and state characteristic controls). ${ }^{28}$

Salary. Because our analysis focuses on salary in tens of thousands of dollars, this makes our regression potentially more susceptible to outliers. The state with the highest salary in the data is California (see Section 2.2 above for an earlier mention on California salary level). However, our results are broadly qualitatively robust to excluding California, as seen in Appendix Table B9. ${ }^{29}$

As mentioned above in Section 3.2, it is difficult to measure non-salary benefits for state legislators. Despite these challenges, however, the 1995 survey data contains information on annual per diem amounts. To examine whether per diems are somehow driving our results, we identified the states where per diem as a proportion of per diem plus salary was the highest in the 1995 data (the average proportion is about one-third). Excluding the highest proportional per diem states (90th percentile and above), the results are qualitatively similar, as seen in Appendix Table B8.

Another concern is that the "real value" of a given salary will vary across the country due to differences in the cost of living. To address this, we test whether our results are robust to deflating salaries using a state-level CPI based on data from Moretti (2013) (data details in Appendix A.4). Appendix Table B7 shows that our main results are qualitatively robust to using a state-level CPI.

\footnotetext{
${ }^{28}$ Kurtz et al. (2006) also show that salary is positively related to what share of a full time job is being a state legislator.

${ }^{29}$ The coefficient for time spent on fundraising is still roughly 0.04 and the coefficient for time spent on legislative activity is still roughly - 0.03 ; an important difference is that the positive relation between pay and time spent on constituent services is now statistically significant at the $5 \%$ level. As an alternative robustness check to excluding California, we also explored using log salary (instead of salary) as a regressor. Using log salary as a regressor, we continue to find a positive relation between pay and time spent on fundraising. However, log salary results are more sensitive to specification; see Appendix A.5 for a more detailed discussion.
} 


\subsection{Subgroup Analysis}

Table 5 further examines the relation between salary and time on fundraising/campaigning using subgroup analysis.

Non-pecuniary benefits of office. In the conceptual framework, we predicted that the larger the degree of non-pecuniary benefits from being in office, the smaller the impact of salary on time spent on fundraising. We use several different strategies for attempting to measure this. First, we look at whether a politician reports it is likely they will run for higher office after serving in the legislature. ${ }^{30}$ For these individuals, we would imagine there is a greater value in getting re-elected insofar as being in office helps facilitate being able to run for higher office in the future. Among individuals who do not think it's likely that they'll run for higher office, there is a significant positive relation between salary and time spent on fundraising, whereas there is no such positive relation among individuals who think it's likely they will run for higher office.

Second, we examine heterogeneity by whether a politician reports it is likely they will do lobbying or consulting after serving in office. We assume that individuals will have better lobbying opportunities the longer they are in office. ${ }^{31}$ There is little difference in the salary coefficient based on whether politicians report expecting to become lobbyists, as see in columns 3 and 4 of Panel A.

However, a concern with the survey question on lobbying/consulting is that politicians may lie about whether they intend to become lobbyists. ${ }^{32}$ Thus, third, we also repeated the analysis using the size of the legislature as a rough proxy for whether politicians have many opportunities to become lobbyists. Specifically, we split legislatures by above-median and below-median levels of spending. The coefficient on salary is larger in states with below-median spending, consistent with salary mattering less in states with fewer post-office opportunities for lobbying.

Competitiveness of elections. In Panel B, we examine split samples according to electoral competitiveness. We create three different measures of competitiveness: (1) whether the legislator

\footnotetext{
${ }^{30}$ We define planning to run for higher office as planning to run for US Congress or a statewide office. We do not consider planning to run for the other legislative chamber, local office, or appointive office as running for a higher office.

${ }^{31}$ An opposite interpretation is also possible. For example, individuals who expect to do lobbying may not mind so much to lose an election because they can then become a lobbyist. It seems likely that a politician can command greater compensation as a lobbyist if they have greater and more detailed experience as a politician. For example, (Bertrand et al. 2014) provide evidence that social connections are important for US federal lobbyists.

${ }^{32}$ We thank an anonymous referee for raising the point that politicians may lie about post-politics careers. Of course, politicians may lie about any aspect of post-politics careers (or about any item on the survey) including possibly the question on intent to run for higher office. However, it seems that politicians may be especially prone to lying about a future interest in lobbying given that there seems to be more social stigma attached to being a lobbyist (at least compared to, say, running for a higher office such as US Congress).
} 
was opposed in their last general election, (2) whether the legislator was opposed in their last primary election, and (3) whether or not the previous general election was "close," defined as being decided by 10 percentage points or less. (For (3), for cases where the general election was uncontested, we code the election as being not close.) Across these three different measures, the responsiveness of fundraising with respect to pay is similar whether or not the district is competitive. This is consistent with the conceptual framework, which does not predict a consistent relation.

Politicians' individual characteristics. Panel $\mathrm{C}$ of Table 5 examines how the relation of salary to time on fundraising varies by other individual characteristics of politicians. Columns 1 and 2 show that the relation of salary to time on fundraising seems actually a bit weaker for Democrats than for Republicans. This is consistent with Republicans potentially having better outside options than Democrats if they don't get re-elected (Fiorina, 1994), but there are many other possible explanations for this result. ${ }^{33}$

We also observe that women respond less with respect to salaries than men. This could possibly be explained by women having a worse outside option than men if they don't get reelected. In addition, Dollar et al. (2001) show that greater female parliamentary representation is associated with less corruption, consistent with the idea that women may be less corrupt than men. In addition, men and women could potentially experience differential impacts of salary increases on their intrinsic motivations. ${ }^{34}$ It is thus possible female and male politicians may respond differently to salary incentives.

Finally, the relation of salary to time on fundraising appears slightly larger for non-white politicians compared to white politicians. While race could encapsulate many relevant variables in this setting, one possibility is differences between whites and non-whites in the non-pecuniary value of the seat. ${ }^{35}$ If non-whites have a lower non-pecuniary value of the seat (e.g., due to less opportunities after office of pursuing lobbying or consulting), then they may be more responsive to salary.

\footnotetext{
${ }^{33}$ For example, Democrats and Republicans could conceivably differ in their level of "intrinsic motivation" and tendency to exhibit "crowd out." We discuss crowd out in general below in Section 4.4

${ }^{34}$ For example, in a very different context, Mellström and Johannesson (2008) show that women exhibit crowd-out in response to getting paid to donate blood, whereas men do not. Other studies in economics reach more skeptical conclusions about crowd-out behavior (presumably for both men and women), such as Esteves-Sorenson and Broce (2016).

${ }^{35}$ If non-whites have a lower outside option than whites outside of politics, then whites should be more responsive in time use with respect to salary.
} 


\subsection{Alternative Explanations / Alternative Theoretical Mechanisms}

Intrinsic Motivation. It is sometimes argued that politicians feel a call to serve the public (Weber, 2004). One alternative explanation for our results (also hinted at above in the discussion of gender) is an intrinsic motivation story. When politicians are paid a low salary, they are intrinsically motivated to serve the public and thus spend more of their time on legislative activities. When salary increases, their intrinsic motivation could be crowded out.

We are unable to rule out that intrinsic motivation could help explain our result that salary is associated with more time on fundraising and less time on legislative activities. In subgroup analysis, we also find that individuals who intend to run for higher office in the future (and thus have a greater non-pecuniary value from getting re-elected) respond less to salary with respect to time fundraising as an outcome. To explain the subgroup result, these individuals would need to experience less crowd-out than those who don't wish to run for higher office in the future. This is possible, but does not seem immediately intuitive. ${ }^{36}$

"Incentives" vs. "Selection." In the conceptual framework and much of the discussion throughout the paper, we implicitly take the selection of legislators as given, and then examine how salaries shape how legislators allocate their time. That is, we focus on the incentive role of salary. We note, however, that salary may also play a role in selecting certain types of politicians. That is, our results could also reflect higher salaries leading individuals to choose to run for office who have a greater affinity for fundraising/campaigning (and perhaps less of an affinity for legislative activities). ${ }^{37}$ This might be possible, for example, if higher salaries led to politicians who were less intrinsically motivated and more focused on money.

Ultimately, it is difficult for us to rule out this interpretation. However, it seems a bit less likely to explain our subgroup analysis results, particularly the result that individuals who intend to run for office in the future are less responsive to salary with respect to time on fundraising.

\footnotetext{
${ }^{36}$ Another behavioral economics theory that is commonly discussed in the context of compensation level is gift exchange (Akerlof, 1982). However, gift exchange does not seem likely to explain our results.

${ }^{37}$ Gagliarducci and Nannicini (2013) use cases where legislators are term limited as a clever way of separating selection effects from incentive effects. Unfortunately, we cannot observe in our data whether an individuals is term limited or not, but rather only whether they live in a state with term limits.
} 


\section{Discussion and Conclusion}

Using a survey of US state legislators, we examine the relationship between salary and time use. Politicians who are paid more spend more time on fundraising, but actually less time on legislative activities. While we cannot rule out omitted variables, the results are robust to adding various controls. The relation of salary to time fundraising is strongest for politicians who do not intend to run for higher office.

Policy-makers have sometimes argued that higher salaries are necessary to achieve high productivity by politicians. We believe that policy-makers should take into account that politicians may respond to salaries on multiple effort margins. That higher salary could lead to unintended consequences in terms of time use, we believe, is also relevant for theoretical work on compensation and organizations.

Our paper has a number of limitations. First, the data presented here are self-reported and given on a 1-5 scale, as opposed to measured on a minute-by-minute basis. It would be fascinating to validate the results of our study if and when such data become available. Second, while our results are robust to inclusion of more and more controls, we do not have a quasi-experimental research design such as a natural experiment or regression discontinuity design. Third, we are unable to empirically distinguish selection and incentive channels of salary on time use. We believe politician time use represents a very interesting research area, and hope that such limitations may be addressed in future work. 


\section{References}

Akerlof, George A, "Labor contracts as partial gift exchange," The Quarterly Journal of Economics, 1982, pp. 543-569.

Altonji, Joseph G., Todd E. Elder, and Christopher R. Taber, "Selection on Observed and Unobserved Variables: Assessing the Effectiveness of Catholic Schools," Journal of Political Economy, 2005, 113 (1), 151-184.

Bandiera, Oriana, Andrea Prat, and Raffaella Sadun, "Managing the Family Firm: Evidence from CEOs at Work," Working Paper 19722, National Bureau of Economic Research December 2013.

Baqir, Reza, "Districting and Government Overspending," Journal of Political Economy, 2002, 110 (6), $1318-1354$.

Barro, Robert, "The Control of Politicians: An Economic Model," Public Choice, 1973, Spring.

Becker, Gary S., "A Theory of the Allocation of Time," The Economic Journal, 1965, 75 (299), 493-517.

_ and George J. Stigler, "Law Enforcement, Malfeasance, and Compensation of Enforcers," Journal of Legal Studies, 1974, $3(1), 1-18$.

Berkman, Michael B., "State Legislators in Congress: Strategic Politicians, Professional Legislatures, and the Party Nexus," American Journal of Political Science, 1994, 38 (4), 1025-1055.

Bertrand, Marianne, Esther Duflo, and Sendhil Mullainathan, "How Much Should We Trust Differences-in-Differences Estimates?," Quarterly Journal of Economics, 2004, 119 (1), 249-275.

_ , Matilde Bombardini, and Francesco Trebbi, "Is it whom you know or what you know? An empirical assessment of the lobbying process," The American Economic Review, 2014, 104 (12), 3885-3920.

Besley, Timothy, "Paying Politicians: Theory and Evidence," JEEA, 2004, 2 (2-3), 193-215.

— and Anne Case, "Does Electoral Accountability Affect Economic Policy Choices? Evidence from Gubernatorial Term Limits," Quarterly Journal of Economics, 1995, 110 (3), 769-98.

Bloom, Nicholas, James Liang, John Roberts, and Zhichun Jenny Ying, "Does Working from Home Work? Evidence from a Chinese Experiment," Quarterly Journal of Economics, 2015, 130 (1), 165-218.

Carey, John M., Richard G. Niemi, and Lynda W. Powell, "State Legislative Survey and Contextual Data, 1995," Technical Report, ICPSR03021-v1, Rochester, NY: University of Rochester 1995.

_ , _ , and _, "State Legislative Survey and Contextual Data, 2002," Technical Report, ICPSR20960-v1, Rochester, NY: University of Rochester 2002 .

Caselli, Francesco and Massimo Morelli, "Bad Politicians," Journal of Public Economics, 2004, 88 (3-4), 759-782.

Dearden, James A and Thomas A Husted, "Do governors get what they want?: An alternative examination of the line-item veto," Public Choice, 1993, 77 (4), 707-723.

Di Tella, Rafael and Raymond Fisman, "Are Politicians Really Paid Like Bureaucrats?," Journal of Law ES Economics, 2004, $47(2), 477-513$.

Diermeier, Daniel, Michael Keane, and Antonio Merlo, "A Political Economy Model of Congressional Careers," American Economic Review, 2005, 95 (1), 347-373.

Dollar, David, Raymond Fisman, and Roberta Gatti, "Are women really the fairer sex? Corruption and women in government," Journal of Economic Behavior 83 Organization, 2001, 46 (4), 423 - 429.

Esteves-Sorenson, Constança and Robert Broce, "Do Monetary Incentives Undermine Performance on Intrinsically Enjoyable Tasks? A Field Test," 2016. Working paper, Yale University.

Ferraz, Claudio and Federico Finan, "Motivating Politicians: The Impacts of Monetary Incentives on Quality and Performance," 2010. Working paper, UC Berkeley.

Fiorina, Morris P., "Divided Government in the American States: A Byproduct of Legislative Professionalism?" American Political Science Review, 1994, 88 (2), pp. 304-316.

Fisman, Raymond, Nikolaj A Harmon, Emir Kamenica, and Inger Munk, "Labor supply of politicians," Journal of the European Economic Association, 2015, 13 (5), 871-905.

Francia, Peter L and Paul S Herrnson, "The impact of public finance laws on fundraising in state legislative elections," American Politics Research, 2003, 31 (5), 520-539.

Freeman, Patricia K and Lilliard E Richardson Jr, "Explaining variation in casework among state legislators," Legislative Studies Quarterly, 1996, pp. 41-56.

Gagliarducci, Stefano and Tommaso Nannicini, "Do better paid politicians perform better? Disentangling incentives from selection," Journal of the European Economic Association, 2013, 11 (2), 369-398.

_ , _ , and Paolo Natichioni, "Moonlighting Politicians," Journal of Public Economics, 2010, 94 (910), 688 - 699.

Gierzynski, Anthony and David Breaux, "Legislative elections and the importance of money," Legislative Studies Quarterly, 1996, pp. 337-357.

Gilligan, Thomas W and John G Matsusaka, "Deviations from Constituent Interests: The Role of Legislative Structure 
and Political Parties in the States," Economic Inquiry, 1995, 33 (3), 383-401.

Groseclose, Timothy and James Snyder, "Buying Supermajorities," American Political Science Review, 1996, pp. 303-315.

_ and Keith Krehbiel, "Golden parachutes, rubber checks, and strategic retirements from the 102d House," American Journal of Political Science, 1994, pp. 75-99.

Hall, Richard L and Robert P Van Houweling, "Avarice and ambition in Congress: Representatives' decisions to run or retire from the US House," American Political Science Review, 1995, pp. 121-136.

Hamermesh, Daniel S and Gerard A Pfann, The economics of time use, Vol. 271, Elsevier, 2005.

Herzog, A Regula and Jerald G Bachman, "Effects of questionnaire length on response quality," Public Opinion Quarterly, 1981, $45(4), 549-559$.

Holmstrom, Bengt and Paul Milgrom, "Multitask Principal-Agent Analyses: Incentive Contracts, Asset Ownership, and Job Design," Journal of Law, Economics, \&3 Organization, 1991, 7, 24-52.

Jones, Wesley H and Gerald Linda, "Multiple criteria effects in a mail survey experiment," Journal of Marketing Research, 1978, pp. 280-284.

Kalt, Joseph P and Mark A Zupan, "The Apparent Ideological Behavior of Legislators: Testing for Principal-Agent Slack in Political Institutions," Journal of Law and Economics, April 1990, 33 (1), 103-31.

Keane, Michael and Antonio Merlo, "Money, Political Ambition, and the Career Decisions of Politicians," American Economic Journal: Microeconomics, 2010, 2 (3), 186-215.

Kotakorpi, Kaisa and Panu Poutvaara, "Pay for politicians and candidate selection: An empirical analysis," Journal of Public Economics, 2011, 95 (7-8), 877-885.

Kurtz, Karl T., Gary Moncrief, Richard G. Niemi, and Lynda W. Powell, "Full-Time, Part-Time, and Real Time: Explaining State Legislators' Perceptions of Time on the Job," State Politics 8 P Policy Quarterly, 2006, 6 (3), $322-338$.

Levitt, Steven D., "Using Repeat Challengers to Estimate the Effect of Campaign Spending on Election Outcomes in the U.S. House," Journal of Political Economy, 1994, pp. 777-798.

Levitt, Steven D and John A List, "Was there really a Hawthorne effect at the Hawthorne plant? An analysis of the original illumination experiments," American Economic Journal: Applied Economics, 2011, 3 (1), 224-238.

List, John A and Daniel M Sturm, "How Elections Matter: Theory and Evidence from Environmental Policy," Quarterly Journal of Economics, 2006, 121 (4), 1249-1281.

Mattozzi, Andrea and Antonio Merlo, "Political Careers or Career Politicians?," Journal of Public Economics, 2008, 92 (3-4), 597-608.

Mellström, Carl and Magnus Johannesson, "Crowding out in blood donation: was Titmuss right?," Journal of the European Economic Association, 2008, 6 (4), 845-863.

Messner, Matthias and Mattias K Polborn, "Paying politicians," Journal of Public Economics, 2004, 88 (12), $2423-2445$.

Miller, Michael G., "The Power of an Hour: Effects of Candidate Time Expenditure in State Legislative Elections," Legislative Studies Quarterly, 2016, 41 (2), 327-359.

Mocan, Naci and Duha T Altindag, "Salaries and work effort: An analysis of the European Union parliamentarians," The Economic Journal, 2013, 123 (573), 1130-1167.

Moretti, Enrico, "Real Wage Inequality," American Economic Journal: Applied Economics, January 2013, 5 (1), 65-103.

National Conference of State Legislatures, A New Perspective on Representative Democracy: A Guide for Legislative Interns., Denver, CO: NCSL, 2000.

_ , "Full and Part-Time Legislatures," 2009.

Poutvaara, Panu and Tuomas Takalo, "Candidate quality," International Tax and Public Finance, 2007, 14 (1), 7-27.

Powell, Lynda W, The Influence of Campaign Contributions in State Legislatures: The Effects of Institutions and Politics, University of Michigan Press, 2012.

Rehavi, Marit M., "Sex and Politics: Do Female Legislators Affect State Spending?," 2007.

Shapiro, Carl and Joseph E Stiglitz, "Equilibrium Unemployment as a Worker Discipline Device," American Economic Review, 1984, 74 (3), 433-44.

Spenkuch, Joerg and David Toniatti, "Political Advertising and Election Outcomes," 2016. Working paper, Northwestern.

Squire, Peverill, "Another Look at Legislative Professionalization and Divided Government in the States," Legislative Studies Quarterly, 1997, 22 (3), 417-432.

Titiunik, Rocio, "Drawing Your Senator From a Jar: Term Length and Legislative Behavior," Political Science Research and Methods, 2014, Forthcoming.

Tomaskovic-Devey, Donald, Jeffrey Leiter, and Shealy Thompson, "Organizational survey nonresponse," Administrative Science Quarterly, 1994, pp. 439-457. 
VanDusky-Allen, Julie, "The Conditional Effect of Term Limits on Electoral Activities," Politics E Policy, 2014, 42 (3), 431-458.

Weber, Max, The Vocation Lectures: Science As a Vocation, Politics As a Vocation, New York, NY: Hackett Pub Co, 2004.

Weiss, Andrew W, "Job Queues and Layoffs in Labor Markets with Flexible Wages," JPE, 1980, 88 (3), 526-38. 
Figure 1: Distribution of Time Use across Legislators for the Three Main Time Use Categories

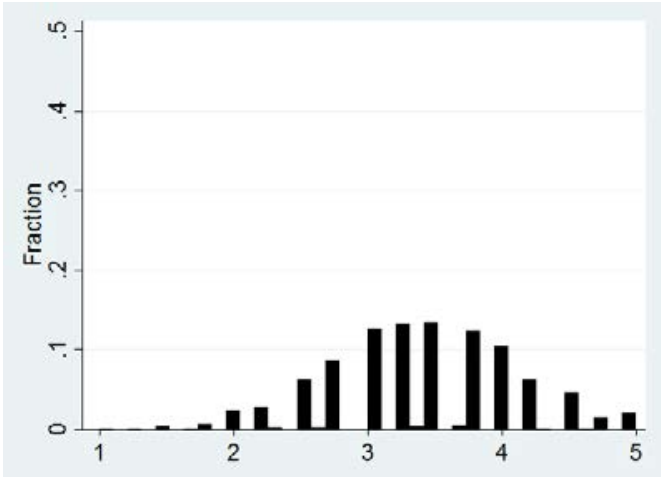

(a) Legislative Activities

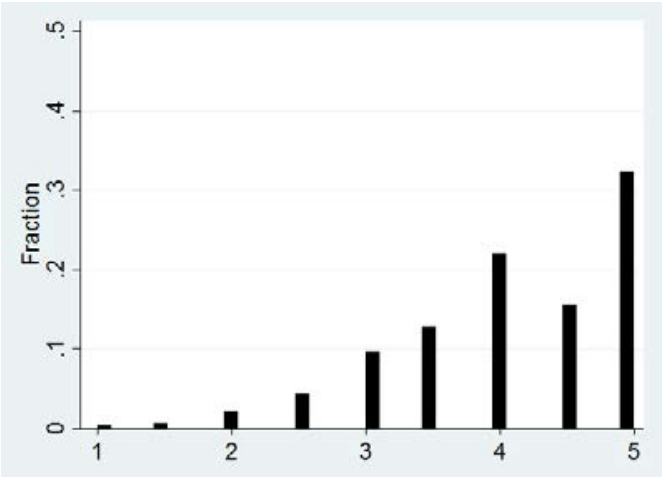

(b) Constituent Services

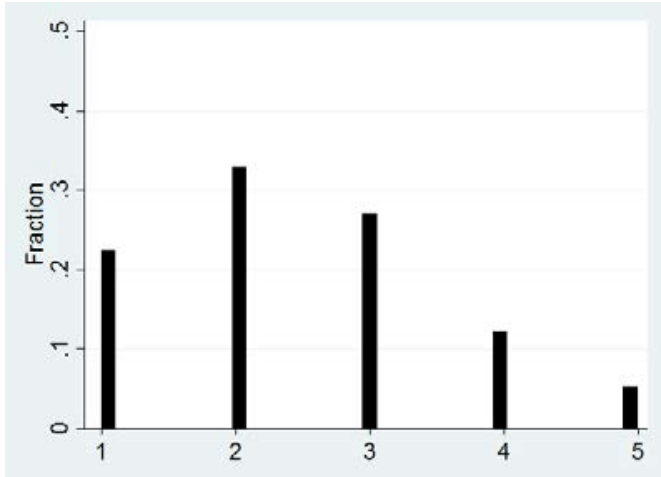

(c) Fundraising \& Campaigning

Notes: An observation is a survey respondent. A given legislator may potentially appear in both the 1995 and 2002 surveys (and thus have 2 observations in our dataset), but we cannot observe this (as it is not possible to link the data at the individual level). "Legislative Activities" is based on four questions; "Constituent Services" is based on two questions; and "Fundraising \& Campaigning" is based on one question. Each question is on a 1-5 Scale. The numbers plotted are averages within each category. 
Table 1: Summary Statistics

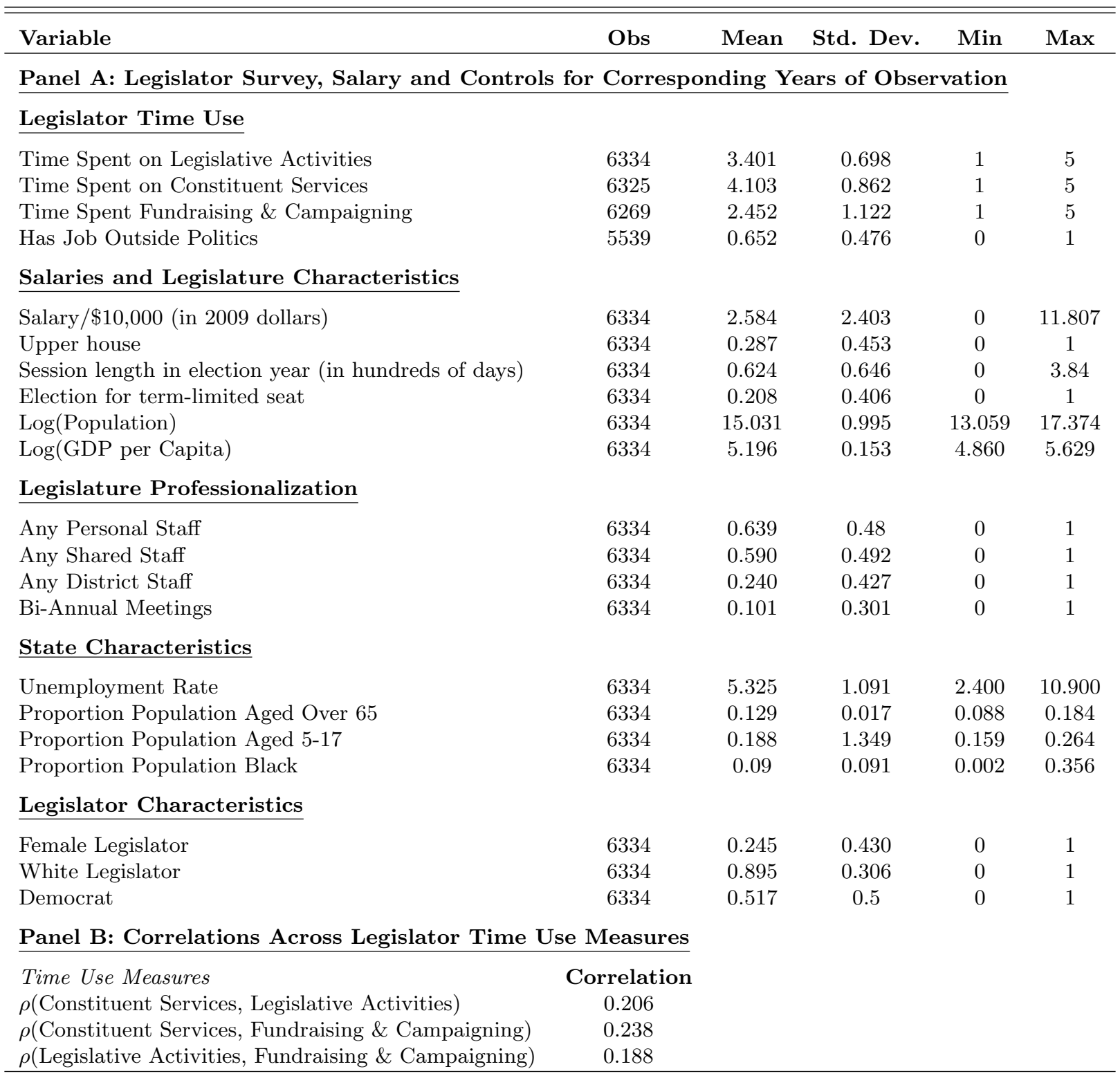

Notes: An observation is a survey respondent, that is, a legislator-year. See Appendix A for further details on variable definitions. A given legislator may potentially appear in both the 1995 and 2002 surveys (and thus have 2 observations in our dataset), but we cannot observe this (as it is not possible to link the data at the individual level). The non-time use variable summary statistics in Panel A are calculated on the sample of survey respondents for whom "time spent on legislative activities" is non-missing. The session length has a maximum of 384 days. This reflects the listing in the 2003 Book of the States for Massachusetts in 2002, where the session is listed as Jan. 2 Dec. 31, 2002 and containing 384 legislative days. Our results are robust to replacing Massachusett's session length with 364 days. Some survey items are missing for some legislators. There is a small amount of missingness in the legislator characteristics data. $0.2 \%$ of observations are missing gender, $1 \%$ of observations are missing Democrat, and $2 \%$ of observations are missing race. Thus, female is defined relative to male or missing; Democrat is defined relative to non-Democrat or missing; and Caucasian is defined relative to non-Caucasian or missing. The correlation coefficients are calculated at the legislator-year level. 
Table 2: Legislative Salary and Time Use

\begin{tabular}{|c|c|c|c|c|}
\hline & $(1)$ & $(2)$ & $(3)$ & $(4)$ \\
\hline \multicolumn{5}{|c|}{ Panel A: Time Spent on Legislative Activities } \\
\hline Salary $/ \$ 10,000$ & $\begin{array}{c}-0.025^{* * *} \\
(0.009)\end{array}$ & $\begin{array}{c}-0.028^{* * *} \\
(0.009)\end{array}$ & $\begin{array}{c}-0.029^{* * *} \\
(0.008)\end{array}$ & $\begin{array}{c}-0.027^{* * *} \\
(0.008)\end{array}$ \\
\hline Observations & 6,334 & 6,334 & 6,334 & 6,334 \\
\hline R-squared & 0.014 & 0.017 & 0.022 & 0.044 \\
\hline \multicolumn{5}{|c|}{ Panel B: Time Spent on Constituent Services } \\
\hline Salary $/ \$ 10,000$ & $\begin{array}{c}0.031 \\
(0.021)\end{array}$ & $\begin{array}{c}0.028 \\
(0.021)\end{array}$ & $\begin{array}{c}0.025 \\
(0.019)\end{array}$ & $\begin{array}{c}0.026 \\
(0.020)\end{array}$ \\
\hline Observations & 6,325 & 6,325 & 6,325 & 6,325 \\
\hline R-squared & 0.084 & 0.085 & 0.104 & 0.112 \\
\hline \multicolumn{5}{|c|}{ Panel C: Time Spent on Fundraising and Campaigning } \\
\hline Salary $/ \$ 10,000$ & $\begin{array}{c}0.053^{* * *} \\
(0.015)\end{array}$ & $\begin{array}{c}0.052^{* * *} \\
(0.016)\end{array}$ & $\begin{array}{c}0.041^{* * *} \\
(0.011)\end{array}$ & $\begin{array}{c}0.041^{* * *} \\
(0.012)\end{array}$ \\
\hline Observations & 6,269 & 6,269 & 6,269 & 6,269 \\
\hline R-squared & 0.049 & 0.059 & 0.064 & 0.071 \\
\hline Baseline Controls & $\mathrm{X}$ & $\mathrm{X}$ & $\mathrm{X}$ & $\mathrm{X}$ \\
\hline Professionalization Controls & & $\mathrm{X}$ & $\mathrm{X}$ & $\mathrm{X}$ \\
\hline State Characteristic Controls & & & $\mathrm{X}$ & $\mathrm{X}$ \\
\hline Region Fixed Effects & & & $\mathrm{X}$ & $\mathrm{X}$ \\
\hline Legislator Characteristic Controls & & & & $\mathrm{X}$ \\
\hline
\end{tabular}

Notes: This table analyzes the relationship between legislative salary and how legislators spend their time in 1995 and 2002. An observation is a legislator-year. Standard errors clustered by state in parentheses. "Time Spent on Legislative Activities" is the average of 4 normalized time use questions (i.e., the average of 4 z-scores). "Time Spent on Constituent Services" is the average of 2 normalized time use questions. "Time Spent on Fundraising and Campaigning" is based on 1 normalized time use question. Normalization is done separately by year. We calculate the average using a "rowmean" in Stata, so that the average is calculated using the questions that an individual answers for that category. "Baseline Controls" are session length in days (measured for the contemporaneous legislative session in the state), a dummy for whether the legislator is in the upper house, a dummy for a seat being term-limited, the log of state population, the log of state GDP, and a year dummy. "Professionalization Controls" are controls for the frequency of meetings, whether legislators have personal staff, whether legislators have shared staff, and whether legislators have district staff. "State Characteristic Controls" are controls for income per capita, proportion of the population aged 65 or older, proportion of the population aged 5-17, proportion of the population that is black, and unemployment rate. "Legislator Characteristic Controls" are controls for whether the legislator is a democrat, whether the legislator is white, and legislator gender. "Region fixed effects" are fixed effects for the 4 census regions. Salary is in 2009 dollars. * significant at 10\%; ** significant at 5\%; *** significant at $1 \%$ 
Table 3: Legislative Salary and Outside Jobs

\begin{tabular}{lcccc}
\hline \hline & $(1)$ & $(2)$ & $(3)$ & $(4)$ \\
\hline Salary/ $\$ 10,000$ & $\begin{array}{c}-0.045^{* * *} \\
(0.012)\end{array}$ & $\begin{array}{c}-0.042^{* * *} \\
(0.010)\end{array}$ & $\begin{array}{c}-0.032^{* * *} \\
(0.007)\end{array}$ & $\begin{array}{c}-0.034^{* * *} \\
(0.007)\end{array}$ \\
Observations & & & & \\
R-squared & 5,539 & 5,539 & 5,539 & 5,539 \\
Baseline Controls & 0.084 & 0.088 & 0.103 & 0.155 \\
Professionalization Controls & $\mathrm{X}$ & $\mathrm{X}$ & $\mathrm{X}$ & $\mathrm{X}$ \\
State Characteristic Controls & & $\mathrm{X}$ & $\mathrm{X}$ & $\mathrm{X}$ \\
Region Fixed Effects & & & $\mathrm{X}$ & $\mathrm{X}$ \\
Legislator Characteristic Controls & & & $\mathrm{X}$ & $\mathrm{X}$ \\
\hline
\end{tabular}

Notes: This table analyzes the relationship between legislative salary and whether legislators have an outside job $(0$ or 1). We use data from both the 1995 and 2002 surveys. An observation is a legislator-year. Standard errors clustered by state in parentheses. Controls are as in Table 2 Salary is in 2009 dollars. * significant at 10\%; ** significant at $5 \%$; *** significant at $1 \%$ 
Table 4: Legislative Salary and Narrow Time Use Categories

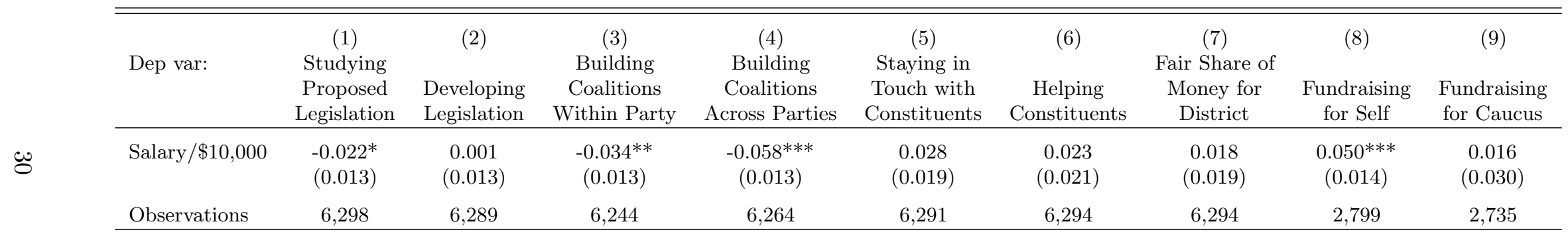

Notes: This table analyzes the relationship between legislative salary and legislator time use in 1995 and 2002 . Standard errors clustered by state in parentheses. An observation is a legislator-year. In each column, the dependent variable is a different normalized time use question. Controls are as in Column 4 of Table 2. Salary is in 2009 dollars. Columns 8-9 are restricted to 2002. Columns 1-7 include two years of data, and hence include year fixed effects. Each narrow category is based on one time use question. "Fair Share of Money for District" refers to time spent "Making sure your district gets a fair share of government money and projects." See Appendix Table B1 for summary statistics of the un-normalized variables.* significant at $10 \%$; ${ }^{* *}$ significant at $5 \%$; ${ }^{* * *}$ significant at $1 \%$ 
Table 5: Heterogeneity across Subgroups in the Relation of Salary to Fundraising/Campaigning

\begin{tabular}{|c|c|c|c|c|c|c|}
\hline \multicolumn{7}{|c|}{ Panel A: Non-Pecuniary Value of Being in Office } \\
\hline & $(1)$ & $(2)$ & (3) & (4) & (5) & (6) \\
\hline Sample: & $\begin{array}{l}\text { No Higher } \\
\text { Office } \\
\text { Objective }\end{array}$ & $\begin{array}{l}\text { Higher } \\
\text { Office } \\
\text { Objective }\end{array}$ & $\begin{array}{c}\text { No Desire } \\
\text { for Lobbying } \\
\text { Job }\end{array}$ & $\begin{array}{c}\text { Desire } \\
\text { for Lobbying } \\
\text { Job }\end{array}$ & $\begin{array}{c}\text { Below } \\
\text { Median State } \\
\text { Expenditures }\end{array}$ & $\begin{array}{c}\text { Above } \\
\text { Median State } \\
\text { Expenditures }\end{array}$ \\
\hline Salary $/ \$ 10,000$ & $\begin{array}{c}0.061^{* * *} \\
(0.012)\end{array}$ & $\begin{array}{l}-0.009 \\
(0.018)\end{array}$ & $\begin{array}{c}0.039^{* * *} \\
(0.012)\end{array}$ & $\begin{array}{c}0.043 \\
(0.028)\end{array}$ & $\begin{array}{c}0.051^{* *} \\
(0.020)\end{array}$ & $\begin{array}{c}0.039^{* *} \\
(0.018)\end{array}$ \\
\hline Observations & 4,713 & 1,553 & 5,331 & 935 & 3,081 & 3,188 \\
\hline \multicolumn{7}{|c|}{ Panel B: Election Competitiveness } \\
\hline & (7) & (8) & $(9)$ & $(10)$ & (11) & $(12)$ \\
\hline Sample: & $\begin{array}{l}\text { Unopposed in } \\
\text { Last General } \\
\text { Election }\end{array}$ & $\begin{array}{l}\text { Opposed in } \\
\text { Last General } \\
\text { Election }\end{array}$ & $\begin{array}{l}\text { Unopposed in } \\
\text { Last Primary } \\
\text { Election } \\
\end{array}$ & $\begin{array}{l}\text { Opposed in } \\
\text { Last Primary } \\
\text { Election } \\
\end{array}$ & $\begin{array}{c}\text { Not (Last General } \\
\text { Election Margin } \\
\leq 10 \%) \\
\end{array}$ & $\begin{array}{c}\text { Last General } \\
\text { Election Margin } \\
\leq 10 \% \\
\end{array}$ \\
\hline Salary $/ \$ 10,000$ & $\begin{array}{c}0.049^{* * *} \\
(0.017)\end{array}$ & $\begin{array}{c}0.043^{* * *} \\
(0.014)\end{array}$ & $\begin{array}{c}0.043^{* * *} \\
(0.014)\end{array}$ & $\begin{array}{c}0.053^{* * *} \\
(0.015)\end{array}$ & $\begin{array}{c}0.040^{* * *} \\
(0.012)\end{array}$ & $\begin{array}{l}0.044^{*} \\
(0.023)\end{array}$ \\
\hline Observations & 1,624 & 4,260 & 3,829 & 2,084 & 5,054 & 1,215 \\
\hline \multicolumn{7}{|c|}{ Panel C: Individual Characteristics } \\
\hline & (13) & $(14)$ & (15) & $(16)$ & (17) & (18) \\
\hline Sample: & Republican & Democrat & Female & Male & White & Non-white \\
\hline Salary $/ \$ 10,000$ & $\begin{array}{c}0.052^{* * *} \\
(0.017)\end{array}$ & $\begin{array}{l}0.030^{*} \\
(0.015)\end{array}$ & $\begin{array}{c}0.010 \\
(0.022)\end{array}$ & $\begin{array}{c}0.048^{* * *} \\
(0.013)\end{array}$ & $\begin{array}{c}0.035^{* * *} \\
(0.012)\end{array}$ & $\begin{array}{c}0.080^{* * *} \\
(0.029)\end{array}$ \\
\hline Observations & 2,945 & 3,240 & 1,524 & 4,733 & 5,619 & 521 \\
\hline
\end{tabular}

Notes: This table analyzes the relationship between legislative salary and legislator time use in 1995 and 2002 and how this varies with legislature, state, and legislator characteristics. An observation is a legislator. Standard errors clustered by state in parentheses. The dependent variable is normalized Time Spent on Fundraising and Campaigning. Controls are as in Column 4 of Table 2. Salary is in 2009 dollars. Columns 1-2 of Panel A refer to whether politicians are likely to run for US Congress or a statewide office after service in the legislature. Columns 3-4 of Panel A refer to whether politicians are likely to do "Lobbying/Consulting" after service in the legislature. * significant at $10 \%$; $* *$ significant at $5 \% ; * * *$ significant at $1 \%$ 


\section{Web Appendix: For Online Publication Only}

This Appendix consists of three parts. Appendix A gives more details on the data. Appendix B provides additional results and robustness checks. Appendix Cpresents a formal model accompanying our conceptual framework.

\section{Appendix A Data Appendix}

\section{A.1 Time Use.}

Information on politician time use was collected from the surveys of legislators done by Carey et al. (1995) and Carey et al. (2002). The 1995 survey was mailed to every upper house legislator and $77 \%$ of lower house legislators. In addition, it was mailed to all former legislators who last served in 1993 or 1994. For the 1995 survey, there were 3,542 legislators who responded and the response rate was $47 \%$. The 2002 survey was mailed to all state legislators. There were 2,982 state legislators who responded and the response rate was $40.1 \%$. Questions asked on time use differ across the two years.

The 1995 survey was described to respondents as a survey focused on better understanding term limits. The 2002 survey did not have such a description.

Table A1: Time Use Survey Questions by Year

\begin{tabular}{lcc}
\hline \hline Question & 1995 Survey & 2002 Survey \\
\hline Time Spent Studying Proposed Legislation & Yes & Yes \\
Time Spent Developing New Legislation & Yes & Yes \\
Time Spent Building Coalitions Within Party & Yes & Yes \\
Time Spent Building Coalitions Across Parties & Yes & Yes \\
Time Spent Keeping in Touch with Constituents & Yes & Yes \\
Time Spent Helping Constituents & Yes & Yes \\
Time Spent Ensuring Fair Share for District & Yes & Yes \\
Time Spent Campaigning and Fundraising & Yes & Yes \\
Time Spent Fundraising for Self & No & Yes \\
Time Spent Fundraising for Caucus & No & Yes \\
\hline
\end{tabular}

Notes: On "Time Spent Building Coalitions Within Party," the survey question asks about "Building coalitions within own party to pass legislation." On "Time Spent Helping Constituents," the survey question asks about "Helping constituents with problems with government." On "Time Spent Building Coalitions Across Parties," the survey question asks about "Building coalitions across parties to pass legislation." On "Time Spent Ensuring Fair Share for District," the question is "Making sure your district gets a fair share of government money and projects."

Legislative Activity. The average of the amount of time on a scale from one to five a legislator reports spending time studying proposed legislation, developing new legislation, building coalitions within their party, and building coalitions across parties.

Constituent Services. The average of the amount of time on a scale from one to five a legislator reports spending time staying in touch with constituents, and helping constituents.

Fundraising and Campaigning. The amount of time on a scale from one to five a legislator reports spending time fundraising and campaigning. 


\section{A.2 Term Limits.}

Obtained from the website of the Council of State Governments for state legislators.

Election for Term-Limited Seat. A dummy for whether or not an election is for a termlimited seat.

We can observe whether the seat is term-limited, but not if an individual is in their final term. It might be interesting to compare politicians based on whether or not they are in their final term (e.g., in Table 5), but we can't do that. The salary-fundraising coefficients are broadly similar if we split the sample based on whether the seat is term-limited or not.

\section{A.3 Other Legislature Characteristics.}

We classify legislatures as part-time or full-time based on the classification of the National Council of State Legislatures. We collected data on legislator staff and legislative session frequency from the Council of State Governments.

Any Personal Staff A dummy for whether a legislator has any staff working directly for him/her.

Any Shared Staff A dummy for whether a legislator has any shared staff.

Any District Staff A dummy for whether a legislator has access to any legislative district staff.

Biennial Session Frequency A dummy for whether or not legislative sessions occur biennially. This variable is equal to zero if sessions occur annually.

We do a robustness check where we restrict the sample to states where legislators don't set their own salaries. The results are also robust to controlling for this variable.

\section{A.4 Other}

Age. We don't control for age in our regressions because the age variable is not available in the 2002 survey. As explained on http://www.icpsr.umich.edu/icpsrweb/ICPSR/studies/20960 (accessed last on July 7, 2016), age was asked in the 2002 survey, but was removed from the dataset by the Principal Investigator.

Multi-member districts. In all the main analyses, we do not exclude multi-member districts. There is no information on multi-member district status for the 2002 survey, but there is information on which states have multi-member districts for the 1995 survey. ${ }^{1}$ We re-did the analyses in column 4 of Table 2 excluding states with multi-member districts in 1995 and reached qualitatively similar results.

Margin of victory in last general election. Panel B of Table 5 splits the sample by whether a legislator's previous general election was "close," defined as having a margin of victory of 10 percentage points or less. Information on margin of victory was asked as part of the politician surveys. We define the margin of victory as the winner's vote share minus the runner up's vote share. There are some cases where the runner-up vote share is reported as greater than the winner's vote share - we do not count such cases as "close," and they are part of the sample in column 11 of Table 5. In the data we use, the vote share numbers are listed in increments of 5 or 10 percentage points.

\footnotetext{
${ }^{1}$ Specifically, for the 1995 survey, there is a variable called "multi." As noted in the codebook, it sometimes indicates the number of members for a district, but sometimes also includes information averaged across districts within a statechamber.
} 
State-level CPI. Moretti (2013) computes price indices at the MSA level. We use his data on prices for food, apparel, transportation, medical, educational, recreational, and other expenses. Specifically, we construct his non-housing total index (including imputed apparel) using the category weights in his code, but construct it using state-level data instead of MSA data. This information is available for 1980 and 1990-2001. We use the data available for 1994 to match with the 1995 survey. For the 2002 survey, we do a linear interpolation to the year 2002 using the available price data.

We also repeated Appendix Table B7 deflating based on a state-level CPI constructed solely from housing data in Moretti (2013) (constructed in the same manner as the non-housing index described above), and obtained qualitatively similar findings.

\section{A.5 Legislator Salary}

As described in the main text, our main regressor is salary in terms of tens of thousands of dollars instead of $\log$ salary. We found that the results under log salary are sensitive to specification. Using log salary as the regressor, we continue to find a significant positive relation between pay and time spent on fundraising; however, the relationship between pay and time spent on constituent services is now statistically significant, whereas there is no longer a statistically significant negative relation between pay and time spent on legislative activity. Using log salary drops New Mexico as an observation because salary is zero. If instead we use $\log (1+$ salary $)$, there is still a positive relation between pay and time spent on fundraising, but it is no longer statistically significant (and the other time use coefficients also are insignificant). In contrast, the inclusion or exclusion of New Mexico has little effect on our main results where salary is in tens of thousands of dollars.

Overall, we continue to see a positive relation between pay and time spent on fundraising when we used log salary. However, the results are much more sensitive when the regressor is log salary instead of absolute salary. This suggests another reason for preferring absolute salary as the regressor of interest compared to log salary.

In the survey data of Carey et al. (1995) and Carey et al. (2002), a legislator salary variable is provided for the 1995 survey, but not for the 2002 survey. Thus, we construct our own measure of annual salary, as described in Section 3.2. The 1995 survey is matched to the 1994-1995 Book of the States (with salary levels as of January 1994), whereas the 2002 survey is matched to the 2002 Book of the States (with salary levels as of March 29, 2001).

As we describe in the text, the initial data were hand-collected from the Book of the States. Recently, tables from past editions of the book have been posted online. These can be found at http://knowledgecenter.csg.org/kc/category/content-type/content-type/book-states (last accessed August 8, 2016). 


\section{Appendix B Additional Tables and Figures}

Table B1: Narrow Time Use Category Summary Statistics

\begin{tabular}{lccccc}
\hline \hline Variable & Obs & Mean & Std. Dev. & Min & Max \\
\hline Developing Legislation & 6289 & 3.426 & 1.04 & 1 & 5 \\
Studying Proposed Legislation & 6298 & 3.77 & 0.947 & 1 & 5 \\
Building Coalitions Within Party & 6244 & 3.256 & 1.052 & 1 & 5 \\
Building Coalitions Across Parties & 6264 & 3.147 & 1.097 & 1 & 5 \\
Helping Constituents & 6294 & 4.099 & 0.962 & 1 & 5 \\
Staying in Touch with Constituents & 6291 & 4.108 & 0.919 & 1 & 5 \\
Ensuring Fair Share for District & 6294 & 3.401 & 1.216 & 1 & 5 \\
Fundraising for Self & 2799 & 2.811 & 1.291 & 1 & 5 \\
Fundraising for Caucus & 2735 & 2.069 & 1.093 & 1 & 5 \\
\hline
\end{tabular}

Notes: An observation is a legislator. Fundraising for self and fundraising for caucus are only observed in 2002 .

Table B2: Legislative Salary Does Not Predict Survey Response

\begin{tabular}{lc}
\hline \hline & Response Percentage \\
\hline Salary $/ \$ 10,000$ & -0.003 \\
& $(0.004)$ \\
Observations & 143 \\
Mean dep var & 0.423 \\
\hline Baseline Controls & $\mathrm{X}$ \\
Professionalization Controls & $\mathrm{X}$ \\
State Characteristic Controls & $\mathrm{X}$ \\
Region Fixed Effects & $\mathrm{X}$ \\
\hline
\end{tabular}

Notes: This table analyzes the relationship between legislative salary and responses to legislator surveys in 1995 and 2002. An observation is a legislature-year (e.g., lower house of Alabama in 2002). For the 1995 survey, we only include upper house legislatures because not all lower house legislators were mailed surveys for the 1995 survey. The dependent variable is the share of legislators who respond for that legislature year. Robust standard errors in parentheses. The controls are the same as in Table 2 except that they are collapsed to the state-chamber-year level. Salary is in 2009 dollars. * significant at $10 \%$;* significant at $5 \%$; *** significant at $1 \%$ 
Figure B1: Sample Distribution of Time Use Across Narrow Categories

Panel A: Legislative Activities
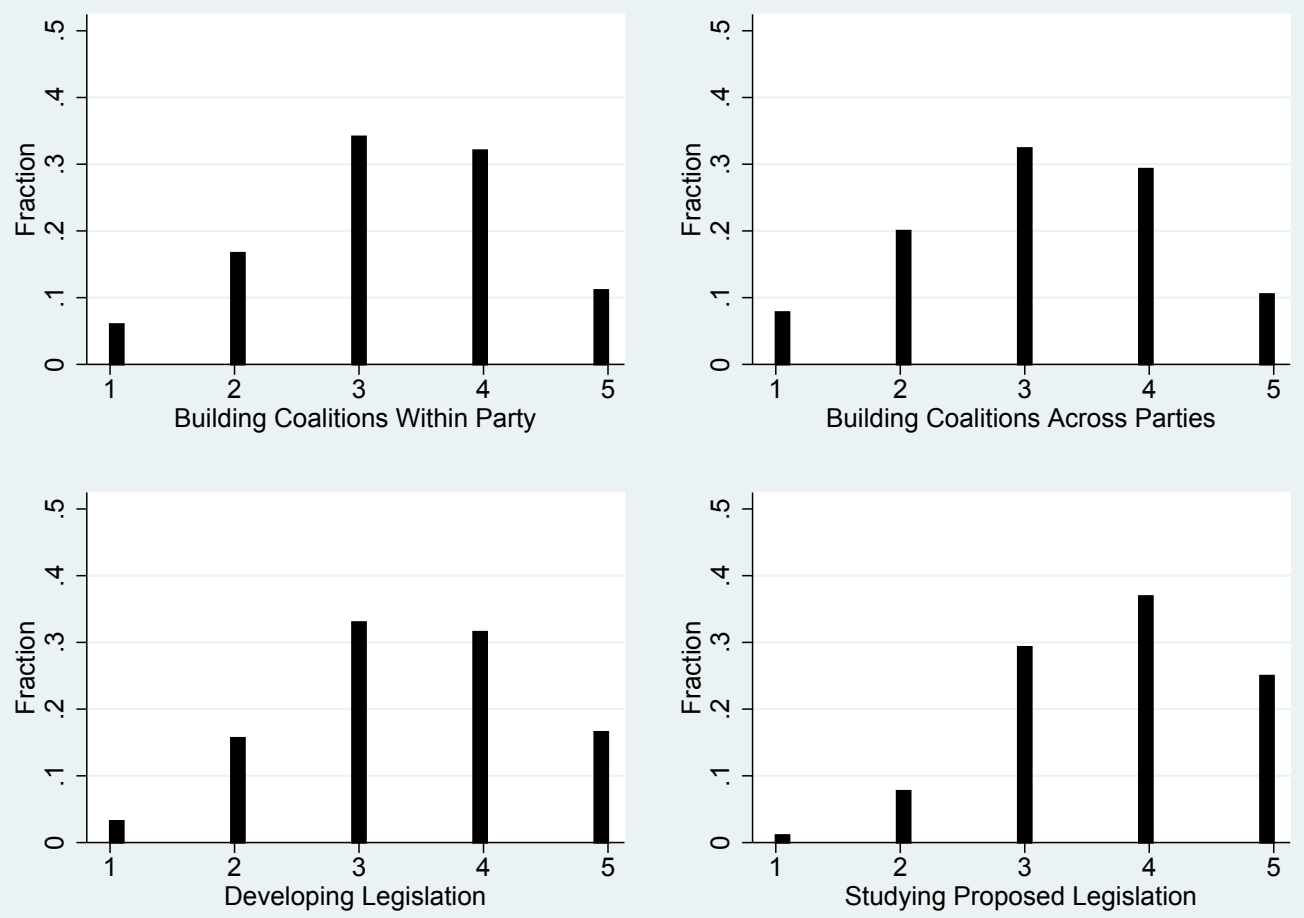

\section{Panel B: Constituent Services}
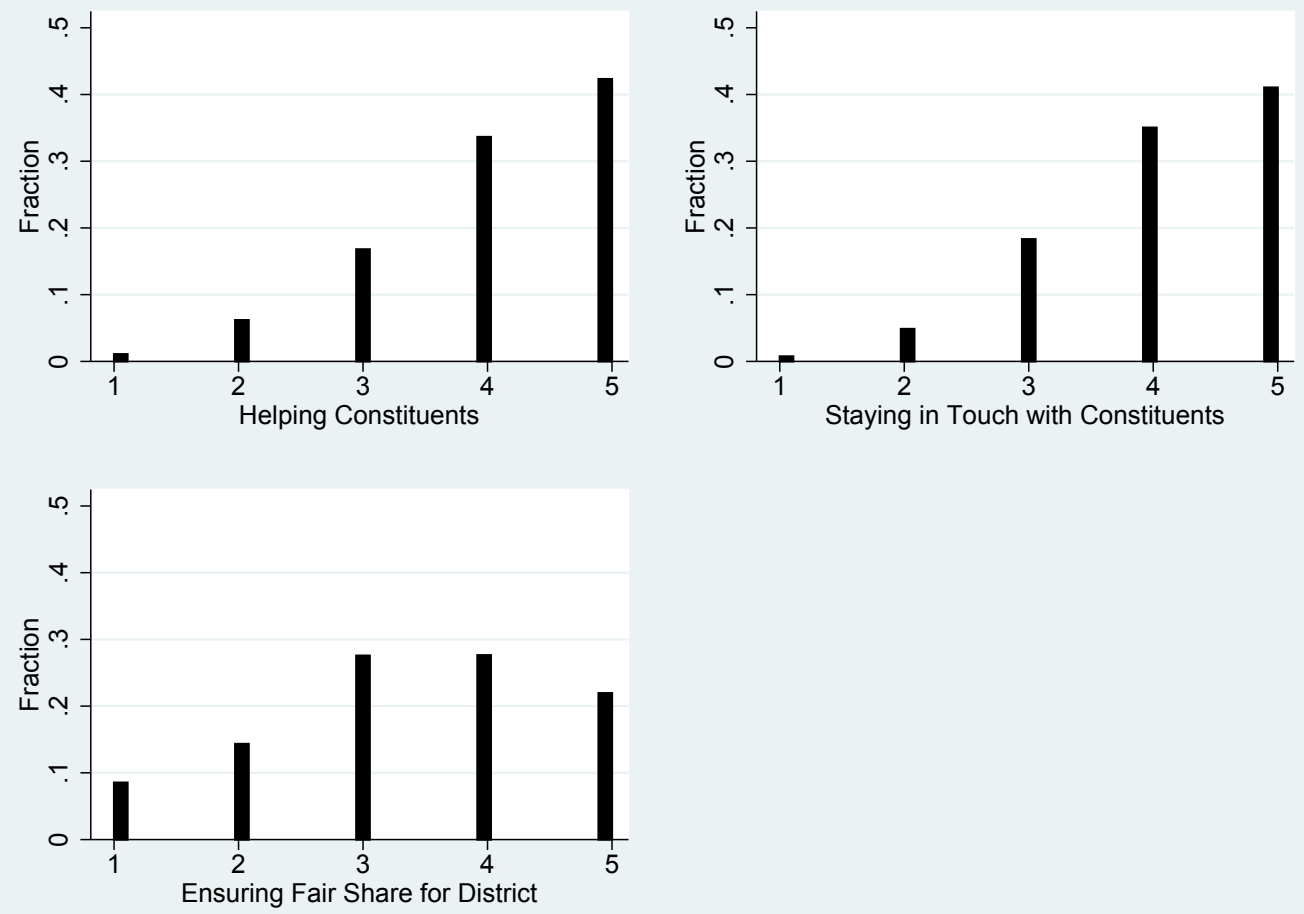
Panel C: Fundraising \& Campaigning
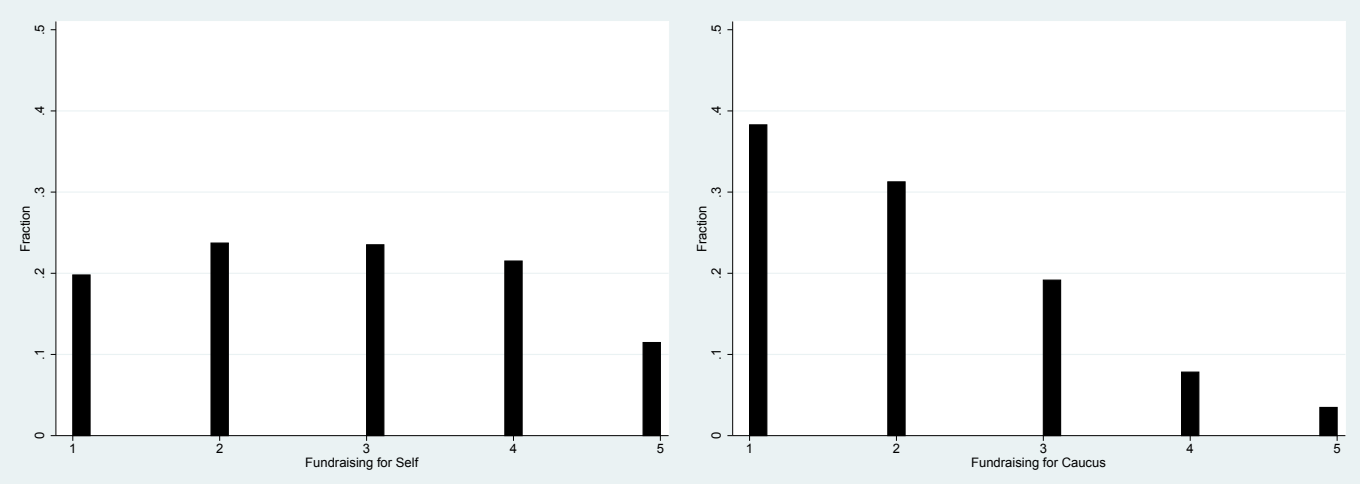

Notes: An observation is a legislator. Time spent raising money for district is only observed in 1995. Time spent getting district fair share, fundraising for self, and fundraising for caucus are only observed in 2002.

Table B3: Legislator Time Use and Bill Authorship

Dep var: Number of Bills Authored, where Primary Author

(1)

$(2)$

(3)

$0.285^{* * *}$
Legislative Activities
$(0.021)$

Constituent Services

0.004

Fundraising \& Campaigning

$0.026^{*}$

$(0.014)$

\begin{tabular}{llll} 
Observations & 5,264 & 5,259 & 5,216 \\
Mean dep var & 2.919 & 2.919 & 2.922 \\
\hline
\end{tabular}

Notes: This table analyzes the relationship between legislative time use and a politician's self-reported number of bills authored. Legislators are asked about the number of bills they authored that became law during the last term. The survey was asked in 1995 and 2002. An observation is a legislator. Standard errors clustered by state in parentheses. All regressions include controls for legislator salary as well as controls included in Column 4 of Table 2 Salary is in 2009 dollars. $*$ significant at $10 \% ; * *$ significant at $5 \%$; $* * *$ significant at $1 \%$

Table B4: Salary and Time Use, Results Restricted to States where Legislators do Not Set Their Own Salaries

\begin{tabular}{lccc}
\hline \hline & $(1)$ & $(2)$ & $(3)$ \\
& $\begin{array}{c}\text { Legislative } \\
\text { Activity }\end{array}$ & $\begin{array}{c}\text { Constituent } \\
\text { Services }\end{array}$ & $\begin{array}{c}\text { Fundraising \& } \\
\text { Campaigning }\end{array}$ \\
\hline Salary $/ \$ 10,000$ & $\begin{array}{c}-0.030^{* * *} \\
(0.008)\end{array}$ & $\begin{array}{c}0.017 \\
(0.024)\end{array}$ & $\begin{array}{c}0.053^{* * *} \\
(0.014)\end{array}$ \\
& & & \\
Observations & 4,109 & 4,105 & 4,070 \\
\hline
\end{tabular}

Notes: The regressions here are similar to those in column 4 of Table 2 . The difference is we eliminate states in which legislator pay is only determined by statute (i.e., not by a compensation commission or the state constitution). * significant at $10 \% ; * *$ significant at $5 \% ; * * *$ significant at $1 \%$ 
Table B5: Salary and Proportion of Legislator Time Spent on Job

\begin{tabular}{lc}
\hline \hline & Proportion of Time Spent on Job \\
\hline Salary $/ \$ 10,000$ & $1.575^{* * *}$ \\
& $(0.558)$ \\
Observations & 2,853 \\
Mean dep var & 65.66 \\
\hline
\end{tabular}

Notes: This table analyzes the relationship between legislative salary and what proportion of their time legislators spend on their legislative job in 2002. The proportion of time spent on the job is asked in 5 bins. We create the dependent variable using the midpoint of each bin. Thus, the dependent variable is equal to $15 \%, 40 \%, 60 \%, 80 \%$, or 95\%. An observation is a legislator. Standard errors clustered by state in parentheses. Controls are as in column 4 of Table 2 Salary is in 2009 dollars. * significant at 10\%; ** significant at 5\%; *** significant at $1 \%$

Table B6: Salary and Time Spent Relative To Other Categories

\begin{tabular}{lccc}
\hline \hline & $\begin{array}{c}(1) \\
\text { Legislative } \\
\text { Activity }\end{array}$ & $\begin{array}{c}(2) \\
\text { Constituent } \\
\text { Services }\end{array}$ & $\begin{array}{c}\text { Fundraising \& } \\
\text { Campaigning }\end{array}$ \\
\hline Salary $/ \$ 10,000$ & $-0.0045^{* * *}$ & 0.0009 & $0.0036^{* * *}$ \\
& $(0.0012)$ & $(0.0012)$ & $(0.0010)$ \\
Observations & 6,036 & 6,036 & 6,036 \\
Mean dep var & 0.346 & 0.415 & 0.239 \\
\hline
\end{tabular}

Notes: This table analyzes the relationship between legislative salary and time spent on an activity relative to the other two time use categories in 1995 and 2002. The regressions are similar to those in column 4 of Table 2 except the dependent variable is different. The dependent variable is time spent on a given activity category (un-normalized, as in Table 1) divided by the sum of time spent on the three activities. Controls are as in column 4 of Table 2 * significant at $10 \% ; * *$ significant at $5 \% ; * * *$ significant at $1 \%$

Table B7: Legislative Salary and Time Use, State CPI

\begin{tabular}{lccc}
\hline \hline & $(1)$ & $(2)$ & $(3)$ \\
& $\begin{array}{c}\text { Legislative } \\
\text { Activity }\end{array}$ & $\begin{array}{c}\text { Constituent } \\
\text { Services }\end{array}$ & $\begin{array}{c}\text { Fundraising \& } \\
\text { Campaigning }\end{array}$ \\
\hline Salary $/ \$ 10,000$ (State CPI) & $\begin{array}{c}-0.026^{* * *} \\
(0.007)\end{array}$ & $\begin{array}{c}0.024 \\
(0.017)\end{array}$ & $\begin{array}{c}0.032^{* * * *} \\
(0.011)\end{array}$ \\
Observations & 6,137 & 6,128 & 6,078 \\
\hline
\end{tabular}

Notes: The regressions here are similar to those in column 4 of Table 2 The difference is we use a state-level CPI based on data from Moretti (2013) instead of a national CPI (as described in Appendix A.4). After this deflation, we multiply salary times the ratio of 2009 CPI to 1980 CPI to convert it to 2009 dollars. * significant at $10 \%$; ** significant at $5 \% ; * * *$ significant at $1 \%$ 
Table B8: Legislative Salary and Time Use, Excluding States with Substantial Per Diem Pay

\begin{tabular}{lccc}
\hline \hline & $\begin{array}{c}(1) \\
\text { Legislative } \\
\text { Activity }\end{array}$ & $\begin{array}{c}(2) \\
\text { Constituent } \\
\text { Services }\end{array}$ & $\begin{array}{c}(3) \\
\text { Fundraising \& } \\
\text { Campaigning }\end{array}$ \\
\hline Salary $/ \$ 10,000$ & $\begin{array}{c}-0.026^{* * *} \\
(0.008)\end{array}$ & $\begin{array}{c}0.029 \\
(0.021)\end{array}$ & $\begin{array}{c}0.039^{* * *} \\
(0.013)\end{array}$ \\
Observations & 5,609 & 5,603 & 5,551 \\
\hline
\end{tabular}

Notes: The regressions here are similar to those in column 4 of Table 2 The difference is we exclude states that have "substantial" per diem pay. We define a state as having substantial per diem pay if its ratio of per diem to annual salary plus per diem is in the top $10 \%$ of the sample in the 1995 data. * significant at $10 \%$; ** significant at $5 \%$; *** significant at $1 \%$

Table B9: Legislative Salary and Time Use, Excluding California

\begin{tabular}{lccc}
\hline \hline & $\begin{array}{c}(1) \\
\text { Legislative } \\
\text { Activity }\end{array}$ & $\begin{array}{c}(2) \\
\text { Constituent } \\
\text { Services }\end{array}$ & $\begin{array}{c}(3) \\
\text { Fundraising \& } \\
\text { Campaigning }\end{array}$ \\
\hline Salary $/ \$ 10,000$ & $-0.028^{* * *}$ & $0.040^{* *}$ & $0.041^{* * *}$ \\
& $(0.009)$ & $(0.017)$ & $(0.013)$ \\
Observations & 6,263 & 6,254 & 6,198 \\
\hline
\end{tabular}

Notes: The regressions here are similar to those in column 4 of Table 2 The difference is we exclude California legislators. $*$ significant at $10 \% ; * *$ significant at $5 \%$; *** significant at $1 \%$ 


\section{Appendix C Model}

We study a two-period model of politicians. ${ }^{2}$ Some state legislatures have term limits, so the first period can be thought of as the non-term limited term, and the second period can be thought of as the term before the term limit. One can also think of the first period as the "normal" period and the second period as the one before retirement.

Our model concerns the behavior of incumbent politicians (the ones studied in our data). The analysis begins after the politician has won their election. We do not study how politicians first get elected.

Incumbent politicians decide how they want to spend their time. Each period, they choose how they would like to spend their $\bar{T}$ units of time. Time spent on fundraising is denoted by $T_{F}$ whereas time spent on law-making is denoted by $T_{L}$. We assume that these are exhaustive activities. However, one can also think of time spent on lawmaking as encompassing as all time not spent on fundraising. Of course, many legislators have time that they spend on other activities (like doing non-politician work). For now, we will think of $\bar{T}$ as encompassing only time for their work as politicians.

A recent edition of Last Week Tonight with John Oliver on 4/3/2016 suggests two aspects of politician fundraising. First, fundraising is viewed as quite important for getting re-elected, and there may be significant returns. ${ }^{3}$ Second, John Oliver's piece describes fundraising as very unpleasant. Many politicians seem to actively dislike having to call wealthy strangers and plead for money. No one dreams of being a politician so that they can spend time fundraising. Rather, many people in politics seem motivated by the desire to serve others and shape policy (e.g., Weber, 2004).

To capture these aspects, we assume that a politician's chance of getting re-elected, $p$, is an increasing function of time spent fundraising. We will additionally assume that $p^{\prime \prime}\left(T_{F}\right)<0$, so that fundraising has diminishing returns. For simplicity, we initially assume that the probability of getting re-elected is unaffected by actual legislative activity. (We relax this later in Section C.2. where we show it is sufficient that the re-election probability responds more to fundraising than to legislative activity.) Second, we assume that politicians receive utility from doing legislative activity $v\left(T_{L}\right)$, and that $v^{\prime}\left(T_{L}\right)>0$ and $v^{\prime \prime}\left(T_{L}\right)<0 .{ }^{4}$

As a condition of being in office, politicians receive a salary $w$ as well as non-pecuniary benefits $b$. The non-pecuniary benefits include non-salary compensation (such as per diems), as well as future benefits from being a politician (such as increased opportunities to run for higher office or be a lobbyist in the future). If a politician loses office, they receive an outside option of utility $r$. Each period, politicians receive utility $v\left(T_{L}\right)+u(c)$, where $u(c)$ is a concave utility function over consumption. For simplicity, we assume that $u(c)=c .^{5}$ There is no discounting. We also assume that the politician prefers winning re-election over losing.

The model is solved backwards. In the second period, there is no possibility of running for

\footnotetext{
${ }^{2}$ While the focus of our models is somewhat different, there are many parallels between our model and that in Chapter 3 of Powell (2012). In her model, a politician chooses between fundraising time oneself, fundraising time for one's party, and other time, whereas our model studies time between legislative activities and fundraising. While elections in our model are simple, there are no elections in her model (she uses what she refers to as a "reduced form" of a candidate's decisions about time on fundraising). However, it seems that the basic tradeoffs across her model and ours are similar.

${ }^{3}$ Note that the John Oliver piece (like a lot of academic work) focuses on US congressional fundraising. While empirical work on the returns to fundraising in political campaigns does not always find positive returns (e.g., Levitt, 1994), Spenkuch and Toniatti (2016) find economically meaningful impacts of TV advertising on vote shares. See (Ansolabehere et al. 2003) for general discussion of money in US politics.

${ }^{4}$ Instead of this assumption, we could alternatively assume that politicians receive no utility from legislative activity, but that there is a convex cost to fundraising.

${ }^{5}$ We have also solved the model assuming a concave utility function with no savings, and all results remain. The results are simpler, however, with linear utility.
} 
re-election. Thus, the politician sets $T_{F}=0$. In the first period, the politician faces the tradeoff between enjoying more $T_{L}$ and spending more time on fundraising which increases the chance of getting elected. Formally, the utility function is:

$$
U=v\left(T_{L, 1}\right)+w+b+p\left(T_{F, 1}\right)[v(\bar{T})+w+b]+\left(1-p\left(T_{F, 1}\right)\right) r
$$

Using the time budget constraint, we plug in $T_{L, 1}=\bar{T}-T_{F, 1}$ to create a one variable problem. To simplify notation, we denote $T_{F, 1}$ by $t$. The politician then solves:

$$
\max _{t} U=\max _{t} v(\bar{T}-t)+w+b+p(t)[v(\bar{T})+w+b-r]+r
$$

This leads to a first-order condition of:

$$
-v^{\prime}(\bar{T}-t)+p^{\prime}(t)[v(\bar{T})+w+b-r]=0
$$

To check whether this is a maximum, we compute the second derivative:

$$
\begin{aligned}
\frac{\partial^{2} U}{\partial t^{2}} & =\frac{\partial U}{\partial t}\left(-v^{\prime}(\bar{T}-t)+p^{\prime}(t)[v(\bar{T})+w+b-r]\right) \\
& =v^{\prime \prime}(\bar{T}-t)+p^{\prime \prime}(t)[v(\bar{T})+w+b-r]<0
\end{aligned}
$$

where we have used that $v^{\prime \prime}$ and $p^{\prime \prime}$ are negative, and that $v(\bar{T})+w+b-r>0$ (i.e., the politician prefers winning re-election to losing). Returning to the first-order condition, denote the left-hand side expression of the first-order condition by $M \equiv-v^{\prime}(\bar{T}-t)+p^{\prime}(t)[v(\bar{T})+w+b-r]$. By the Implicit Function Theorem, we have that:

$$
\begin{aligned}
\frac{\partial t^{*}}{\partial w} & =\frac{-\frac{\partial M}{\partial w}}{\frac{\partial M}{\partial t}}=\frac{-p^{\prime}\left(t^{*}\right)}{v^{\prime \prime}\left(\bar{T}-t^{*}\right)+p^{\prime \prime}(t)[v(\bar{T})+w+b-r]} \\
& =\frac{p^{\prime}\left(t^{*}\right)}{-v^{\prime \prime}\left(\bar{T}-t^{*}\right)-p^{\prime \prime}(t)[v(\bar{T})+w+b-r]}
\end{aligned}
$$

The numerator is positive because $p$ is increasing in time on fundraising. Further, note that the denominator is signed positive by the second-order condition. Therefore, $\frac{d t^{*}}{d w}>0$. The intuition is simple: as the wage is increased, the politician faces a greater return to spending time on getting re-elected.

\section{C.1 Interaction Terms}

There are a number of possible interaction terms that may be of interest:

1. How does the derivative of interest (responsiveness of time on fundraising with respect to salary) vary with the level of non-pecuniary benefits?

2. How does the derivative of interest vary with the competitiveness of elections?

3. How does the derivative of interest vary with a politician's outside option?

To address difficulties associated with analyzing the cross-derivatives for general functional forms, we assume that $v(x)=x^{1 / 2}, p(x)=x^{1 / 2}$, and $\bar{T}=1$. To simplify notation, we also define $\theta \equiv 1+w+b-r$, 
which is a measure of how much a politician would like to get re-elected relative to their outside option. These assumptions yield the below problem:

$$
\max _{t}(1-t)^{1 / 2}+w+b+t^{1 / 2} \theta+r
$$

This leads to a first order condition of:

$$
\begin{aligned}
-.5(1-t)^{-1 / 2}+.5 t^{-1 / 2} \theta & =0 \\
t^{*} & =\frac{\theta^{2}}{1+\theta^{2}}
\end{aligned}
$$

Now, we can calculate our initial derivative of interest for this functional form:

$$
\begin{aligned}
\frac{\partial t^{*}}{\partial w} & =\frac{\partial}{\partial w}\left(\frac{\theta^{2}}{1+\theta^{2}}\right) \\
& =\frac{2 \theta \frac{\partial \theta}{\partial w}\left(1+\theta^{2}\right)-\theta^{2} * 2 \theta \frac{\partial \theta}{\partial w}}{\left(1+\theta^{2}\right)^{2}} \\
& =\frac{2 \theta}{\left(1+\theta^{2}\right)^{2}}
\end{aligned}
$$

QUESTION 1. We want to compute $\frac{\partial^{2} t^{*}}{\partial w \partial b}$ :

$$
\begin{aligned}
\frac{\partial^{2} t^{*}}{\partial w \partial b} & =\frac{\partial}{\partial b}\left(\frac{2 \theta}{\left(1+\theta^{2}\right)^{2}}\right) \propto \frac{\partial}{\partial b}\left(\frac{\theta}{\left(1+\theta^{2}\right)^{2}}\right) \\
& =\frac{\frac{\partial \theta}{\partial b}\left(1+\theta^{2}\right)^{2}-\theta * 2\left(1+\theta^{2}\right) * 2 \theta \frac{\partial \theta}{\partial b}}{\left(1+\theta^{2}\right)^{4}} \\
& =\frac{\left(1+\theta^{2}\right)-\theta * 2 * 2 \theta}{\left(1+\theta^{2}\right)^{3}}=\frac{1-3 \theta^{2}}{\left(1+\theta^{2}\right)^{3}}
\end{aligned}
$$

Thus, $\operatorname{sgn}\left(\frac{\partial^{2} t^{*}}{\partial w \partial b}\right)=\operatorname{sgn}\left(1-3 \theta^{2}\right)$. This is negative when $1<3 \theta^{2}$, or when $\theta>\sqrt{1 / 3}$. Thus, if the drive to get re-elected is sufficiently high (i.e., $\theta>\sqrt{1 / 3}$ ), then $\frac{\partial^{2} t^{*}}{\partial w \partial b}<0$.

Thus, assuming that there is sufficient value put on getting elected, the cross-partial will be negative. This means that, for politicians who have a large non-pecuniary value of the job $(b)$, the derivative of interest is smaller, as these individuals are already more motivated to invest time in fundraising. Intuitively, for politicians with larger $b$, salary may not be the main benefit from the job, and their time use will be less responsive as a function of salary.

QUESTION 2. So far, we have not defined the competitiveness of elections. To do so now, let $c$ be the probability that an election is competitive. Specifically, with probability $c$, the election is competitive and the incumbent has a probability $p\left(T_{F, 1}\right)$ of winning. However, with probability $1-c$ the election is non-competitive and the incumbent wins regardless of how much time is spent on fundraising. The timing is as follows. First, the politician chooses his or her time allocation knowing $c$, but not knowing whether the election is competitive or not. Thus, the agent's problem can be written now as: 


$$
\begin{aligned}
& \max _{t} v(\bar{T}-t)+w+b+c[p(t)[v(\bar{T})+w+b]+(1-p(t)) r]+(1-c)[v(\bar{T})+w+b] \\
= & \max _{t} v(\bar{T}-t)+w+b+c[p(t)[v(\bar{T})+w+b-r]+r]+(1-c)[v(\bar{T})+w+b] \\
= & \max _{t} v(\bar{T}-t)+w+b+c[p(t) \theta+r]+(1-c)[\theta+r]
\end{aligned}
$$

Using the first order condition and the implicit function theorem, one can show that this leads to a derivative of $\frac{\partial t^{*}}{\partial w}=\frac{c p^{\prime}\left(t^{*}\right)}{-v^{\prime \prime}\left(\bar{T}-t^{*}\right)-c p^{\prime \prime}\left(t^{*}\right) \theta}$, which is positive. Now we turn to a specific functional form so as to be able to analyze interaction effects.

$$
\max _{t}(1-t)^{1 / 2}+w+b+c t^{1 / 2} \theta+r+(1-c)[\theta+r]
$$

The first-order condition is now:

$$
\begin{aligned}
-.5(1-t)^{-1 / 2}+.5 c t^{-1 / 2} \theta & =0 \\
t^{*} & =\frac{c^{2} \theta^{2}}{1+c^{2} \theta^{2}} \\
\frac{\partial t^{*}}{\partial w} & =\frac{\partial}{\partial w} \frac{c^{2} \theta^{2}}{1+c^{2} \theta^{2}} \\
& =\frac{2 c^{2} \theta\left(1+c^{2} \theta^{2}\right)-c^{2} \theta^{2} * 2 c^{2} \theta}{\left(1+c^{2} \theta^{2}\right)^{2}} \\
& =\frac{2 c^{2} \theta}{\left(1+c^{2} \theta^{2}\right)^{2}}
\end{aligned}
$$

Note that if $c=0$, then the agent will choose $t^{*}=0$ and this allocation is independent of the salary. Next, we compute $\frac{\partial^{2} t^{*}}{\partial w \partial c}$ :

$$
\begin{aligned}
\frac{\partial^{2} t^{*}}{\partial w \partial c} & =\frac{\partial}{\partial c}\left(\frac{2 c^{2} \theta}{\left(1+c^{2} \theta^{2}\right)^{2}}\right) \propto \frac{\partial}{\partial c}\left(\frac{c^{2} \theta}{\left(1+c^{2} \theta^{2}\right)^{2}}\right) \\
& =\frac{2 c \theta\left(1+c^{2} \theta^{2}\right)^{2}-c^{2} \theta * 2\left(1+c^{2} \theta^{2}\right) * 2 c \theta^{2}}{\left(1+c^{2} \theta^{2}\right)^{4}} \\
& =2 c \theta\left(\frac{1-c^{2} \theta^{2}}{\left(1+c^{2} \theta^{2}\right)^{3}}\right)
\end{aligned}
$$

Thus, we have that $\operatorname{sgn}\left(\frac{\partial^{2} t^{*}}{\partial w \partial c}\right)=\operatorname{sgn}\left(1-c^{2} \theta^{2}\right)$. This cross-partial is ambiguously signed. It will be positive if $\theta<\frac{1}{c}$ and will be negative if $\theta>\frac{1}{c}$. From our discussion above, we are assuming that $\theta$ is often sizable because legislators presumably want to keep their seats. On the other hand, we know that many state legislative races in the US are non-competitive. This makes it difficult to sign the cross-derivative.

It is difficult a priori to think about how competition will affect the relation of salary and time on fundraising. Competition seems likely to increase time on fundraising in general, as there is less value to "investing" time on fundraising when it is likely the politician will win for sure (Powell, 
2012). However, the second derivative is less clear.

QUESTION 3. We want to compute $\frac{\partial^{2} T_{F, 1}}{\partial w \partial r}$ :

$$
\begin{aligned}
\frac{\partial^{2} T_{F, 1}}{\partial w \partial r} & =\frac{\partial}{\partial r}\left(\frac{2 \theta}{\left(1+\theta^{2}\right)^{2}}\right) \propto \frac{\partial}{\partial r}\left(\frac{\theta}{\left(1+\theta^{2}\right)^{2}}\right) \\
& =\frac{\frac{\partial \theta}{\partial r}\left(1+\theta^{2}\right)^{2}-\theta * 2\left(1+\theta^{2}\right) * 2 \theta \frac{\partial \theta}{\partial r}}{\left(1+\theta^{2}\right)^{4}} \\
& =\frac{\partial \theta}{\partial r} \frac{d^{2} t^{*}}{d w d b}=\frac{3 \theta^{2}-1}{\left(1+\theta^{2}\right)^{3}} \\
\operatorname{sgn}\left(\frac{\partial^{2} T_{F, 1}}{\partial w \partial r}\right) & =\operatorname{sgn}\left(3 \theta^{2}-1\right)
\end{aligned}
$$

This is the mirror image of the result with respect to $b$.

Assuming that the desire to get re-elected is sufficiently high (i.e., $1+w+b-r>\sqrt{1 / 3}$ ), we have thus proven four hypotheses:

H1: An increase in salary leads to more fundraising.

H2: When non-pecuniary benefits are larger, this derivative is smaller.

H3: The competitiveness of elections does not have a clear impact on the derivative.

H4: When a politician's outside option is larger, this derivative is larger.

\section{C.2 Allowing Legislative Activities to Have a Return in Getting Re-elected}

In the basic model, there was no return for legislative activities in terms of getting re-elected. This assumption can be modified. Suppose that the probability of getting re-elected is $p\left(T_{L, 1}+\theta T_{F, 1}\right)$ where $\theta$ expresses the return to fundraising relative to legislating.

For simplicity, let us begin by assuming $u(r)=0$. Then, the politicians solves the problem:

$$
\max _{T_{F, 1}} U=\max _{T_{F, 1}} v\left(\bar{T}-T_{F, 1}\right)+u(w+b)+p\left(T_{L, 1}+\theta T_{F, 1}\right)[v(\bar{T})+u(w+b)]
$$

Applying the Implicit Function Theorem, we obtain that:

$$
\begin{aligned}
\frac{\partial T_{F, 1}}{\partial w} & =\frac{-\frac{\partial M}{\partial w}}{\frac{\partial M}{\partial T_{F, 1}}}=\frac{(\theta-1) p^{\prime}\left(\bar{T}+(\theta-1) T_{F, 1}\right) u^{\prime}(w+b)}{-v^{\prime \prime}\left(\bar{T}-T_{F, 1}\right)-(\theta-1)^{2} p^{\prime \prime}\left(\bar{T}+(\theta-1) T_{F, 1}\right)[v(\bar{T})+u(w+b)]} \\
& =\frac{(\theta-1) p^{\prime} u^{\prime}}{-v^{\prime \prime}-(\theta-1)^{2} p^{\prime \prime} *[v(\bar{T})+u]}
\end{aligned}
$$

Note that $p^{\prime}$ and $u^{\prime}$ are positive, so the numerator will have the same sign as $(\theta-1)$. Also, note that $v^{\prime \prime}$ and $p^{\prime \prime}$ being negative implies that the denominator is negative. Thus, $\operatorname{sgn}\left(\frac{\partial T_{F, 1}}{\partial w}\right)=\operatorname{sgn}(\theta-1)$. This means that, if there is a greater return to fundraising than legislative activity in terms of getting re-elected, then the main comparative will hold. 


\section{Appendix References}

Ansolabehere, Stephen, John M. de Figueiredo, and Jr Snyder James M., "Why is There so Little Money in U.S. Politics?," Journal of Economic Perspectives, March 2003, 17 (1), 105-130.

Levitt, Steven D., "Using Repeat Challengers to Estimate the Effect of Campaign Spending on Election Outcomes in the U.S. House," Journal of Political Economy, 1994, pp. 777-798.

Moretti, Enrico, "Real Wage Inequality," American Economic Journal: Applied Economics, January 2013, 5 (1), 65-103.

Powell, Lynda W, The Influence of Campaign Contributions in State Legislatures: The Effects of Institutions and Politics, University of Michigan Press, 2012.

Spenkuch, Joerg and David Toniatti, "Political Advertising and Election Outcomes," 2016. Working paper, Northwestern.

Weber, Max, The Vocation Lectures: Science As a Vocation, Politics As a Vocation, New York, NY: Hackett Pub Co, 2004. 